

\title{
Time preferences: do they matter in bargaining?
}

\author{
Paola Manzini \\ Queen Mary, University of London and IZA
}

October 2001

\begin{abstract}
Experimental studies of bargaining generally impose time preferences on subjects, in the sense that in case of disagreement, the experimenter reduces the size of the surplus bargained over by imposing exogenously some monetary cost. Contrary to this practice, in this study time preferences are first elicited in a preliminary phase, and then bargaining begins. I show that although subjects are sensitive to the timing of a monetary reward, this plays no role in determining bargaining behaviour. Furthermore, when the bargaining game is played in conventional experimental setting with monetary cost of delay, these do have an impact on subjects' conduct in negotiations.
\end{abstract}

JEL Classification: C78, C91.

Keywords: bargaining, time preferences, experiments.

Correspondence to: Paola Manzini, Department of Economics, Queen Mary, University of London, Mile End Road, London E1 4NS, U.K. (tel: +44(0)20-7882 5083, fax: +44(0)20-8983 3580, e-mail: p.manzini@qmw.ac.uk, http://www.econ.qmw.ac.uk/ ugte172).

I am indebted to Robin Cubitt, Steffen Huck, Marco Mariotti, Karim Sadrieh, Martin Sefton, Anne Spencer, Bob Sugden and Nick Vriend for very thorough, helpful and patient advice on the experimental design and related matters. I owe special thanks to Daniela Di Cagno: without her help it would have been impossible to run the experiment. The usual disclaimers apply. Financial support from the Queen Mary Social Science Research Fund is gratefully acknowledged. 


\section{Introduction}

The role that time plays in economic decisions and behaviour is paramount, and has long been recognised. The literature is huge ${ }^{1}$, dating back at least to the $17^{\text {th }}$ century, and models of intertemporal allocation of resources are the staple diet for undergraduate students in economics. However, actual behaviour is often at odds with conventional economic wisdom².

We all shop around for the lower mortgage rate or the highest savings rate, but when the transaction is not purely financial behaviour seems less 'rational'. For instance, in the real estate market, there is evidence ${ }^{3}$ that we tend to stay focused on achieving the maximum possible price, and only a small proportion of house sellers does revise the asking price downwards, in spite of the obvious trade-off between sale price and time on the market.

More generally, casual evidence would suggest that when people are involved in a task where time is not the only relevant dimension, its effect may be somewhat "watered down" 4 . My objective in this paper is to test this hypothesis. The specific task I consider is a bargaining situation, so as to study whether or not bargaining over time incorporates peculiar features which cannot be accounted for by traditional experimental design.

My results indicate that, although when involved in a task which concern purely time subjects do 'react' to it, when the principal task is such that time is only one of the relevant features involved, it seems not to matter. I will refer to this as time prominence (or lack of it).

The reason why I look at a bargaining task is that time preferences (i.e. impatience) are considered as one of the fundamental forces driving the outcome in non-cooperative models of bargaining $^{5}$. This feature is translated in experimental settings by modelling agents' preference for an earlier (rather than a delayed) agreement by means of an exogenous reduction of the surplus bargained over every time disagreement occurs. So if, say, subjects are negotiating over the division of a surplus between them, the experimenter can impose a rate of time preference $\tau_{\mathrm{i}}$ on player $\mathrm{i}$,

1 For choices among 'single' time dependent outcomes Fishburn and Rubinstein (1980) provide representation theorems for utility maximising agent with a monotonic and continuous preference ordering on $\mathrm{X} \times \mathrm{T}$ (where $\mathrm{X}$ is the set of outcomes and $\mathrm{T}$ is the set of times). Meyer (1976) considers the case of preferences over sequences of time dependent outcomes, as more recently Fishburn and Edwards (1997). See Frederick, Loewenstein and O'Donoghue (2001) for a thorough review of these issues.

${ }^{2}$ The stark contrast between actual behaviour and the theoretical conjecture on Homo Oeconomicus' conduct are commanding more and more the attention of the professionals. See for instance Thaler (1991), Elster (1998), Rabin (1998), O'Donoghue and Rabin (1999), Goeree and Holt (2000), Starmer (2000), Henrich et al. (2001) and Loewenstein (2001) to cite just a few.

${ }^{3}$ Ortalo-Magné and Merlo (2000) find that only about $25 \%$ of house sellers in England lower the selling price (after an average of 11 weeks on the market). Anglin et al (2001) finds a higher proportion for Canada (around 46\%).

${ }^{4}$ The fact that "distractors" worsen task performance is well reserached in the cognitive neurosciences. For instance, interference (from subsequent terms in a list of numbers) impairs short term memory (see Gazzaniga, Ivry and Mangum (1998), chapter 7, and references therein), and time preferences are dramatically affected by addiction (see for instance Bickel and Marsch, 2001).

${ }_{5}^{5}$ Theoretical non-cooperative bargaining models with an alternating offers structure and proportional discounting have proven somewhat more popular than those with fixed costs of delay; even more so in the 
(corresponding to the intertemporal discount factor $\delta_{i}=\frac{1}{1+\tau_{i}}$ ) by having the surplus reduced by a factor $^{6} \delta_{i}$ at every round following disagreement (so that subject i's share $x_{i}$ is worth $\delta_{i}^{t} x_{i}$ if agreement is reached at time $\mathrm{t}$ ). Whether or not this is a legitimate way to render time preferences in a laboratory environment is then crucial for the interpretation of the experimental results.

The development of theoretical tools for analysing non cooperative bargaining and its relevance for real life together have fostered the flourishing of a rich literature on experimental models of bargaining over "shrinking" pies $^{7}$. But all these experiments share the problem that they try and implement the theoretical framework of bargaining over time in experimental settings where on the contrary time has no role at all. What these experiments really study is therefore the extent to which backward induction type of reasoning is "used", if at all, by subjects in negotiations.

In this paper I therefore consider alongside "conventional" experimental design - where time is modelled as some cost to be incurred in case of failure to reach immediate agreement - a bargaining game where disagreement entails receiving the agreed share at a later point in time. In order to make the "conventional" and "real time" protocols comparable, real time bargaining is preceded by a stage in which the subjects' time preferences are assessed.

There is a problem, though, with addressing the issue of time preferences directly, as the debate on how actual time preferences should be modelled is still as open as it is unsettled. A number of violations of representations of time preference of the form outlined above have been noted ${ }^{9}$. Often "dread" and "savouring" effects are observed", which refer to the fact that people prefer to postpone a pleasant activity (so as to enjoy also the "build up" to it), or to anticipate an unpleasant task (so as to avoid contemplating this unfavourable outcome for too long).

experimental bargaining literature. For a review of the huge literature sparked by Rubinstein (1982), see for instance Osborne and Rubinstein (1990) and Binmore, Osborne and Rubinstein (1992).

${ }^{6}$ Such discount factor can be imposed to be the same for both players (as for instance in Binmore, Shaked and Sutton (1985), Guth and Tietz (1988), Neelin, Sonnenschein and Spiegel, 1988), or different (as in Ochs and Roth, 1989).

${ }^{7}$ See Roth (1995) for a thorough survey of this vast literature; Rapoport et al. (1990) consider alternating offers bargaining models where the cost of delay is some fixed constant.

${ }^{8}$ The debate has initially focused on checking the accuracy of subgame perfect equilibrium as a predictor of the outcome of experimental negotiations. Failing that, the next step has been to trying and individuate possible heuristics used by experimental subjects. The evidence on this is somewhat mixed (see e.g. Prasnikar and Roth (1992), who investigate off the equilibrium path incentives to players to conform to behaviour which is subgame perfect in both ultimatum and "best shot" games), and it is not uncommon to observe subjects reject an offer and make a counter-proposal that leaves them with a smaller payoff than the one previously rejected. Thus, there might be fairness considerations lurking in the background, which may trigger rejection of an 'insultingly low' offer. This in turn poses the problem of detecting what sort of agreements people deem fair; on this, see for instance Binmore, Morgan, Shaked and Sutton (1991). However, see also Forsythe et al. (1994) for an example where bargaining power is totally exploited in the absence of punishment. Other studies of fairness are for instance Bolton and Ockenfels (2001) and Fehr and Gachter (2000).

${ }^{9}$ For a survey of these violations, see Loewenstein and Thaler (1989) or Loewenstein and Prelec (1992). For a thorough treatment of issues concerning choice over time see Elster and Loewenstein (1992) and more recently Frederick, Loewenstein and O'Donoghue (2001).

${ }^{10}$ Results of this kind have been obtained for instance by Loewenstein (1987). 
Furthermore, observed preferences are rarely stationary, and people often exhibit a strict preference for immediacy: they may be indifferent between some immediate outcome and a delayed one, but in case they are both brought forward in time, the immediate outcome loses completely its attractiveness $^{11}$. Besides, there is an abundance of papers which argue that discounting behaviour is more consistent with hyperbolic rather than exponential discounting ${ }^{12}$.

In this paper I take an agnostic view on the competing theories on time preferences, and do not fully investigate alternative possible representations. As it will become clear further below, for my purposes it is not necessary to estimate discount factors ${ }^{13}$ precisely. It is enough for me to be able to establish that subjects are indeed sensitive to the timing of a monetary reward by some form of (incentive compatible) measure of time attitude. Then, I will be able to show that the experimental designs conventionally adopted for bargaining games fail to approximate negotiations over timedependent outcomes, where bargaining behaviour is totally unaffected by the cost of delay.

The experimental design for this paper is described in the next section. Section 3 overviews the results, which are discussed in detail in sections 4 and 5. Section 6 concludes.

\section{Experimental design}

The experiment was conducted over two consecutive days (during term time) at the Economics Department of LUISS University in Rome ${ }^{14}$. The subjects were first year undergraduates with no prior exposure to Game Theory.

Three treatments were considered. The first one consisted of two stages. In the first stage time preferences (over delays of one and two months) were elicited by using a modification of the Becker-Marschack-De Groot procedure ${ }^{15}$, hence this treatment is referred to as BDM. In the second stage subjects played a two round bargaining game on the division of a sum of money (300 monetary units $\left.^{16}\right)$. The other two treatments consisted of the second stage only (bargaining). As explained more in detail below, in the BDM treatment delayed agreement (i.e. agreement in the second round) resulted in subjects receiving their payment with a time lag of one month. For the other two treatments, agreement in the second round entailed either a payment of a fixed fee (out

${ }^{11}$ This phenomenon is reminiscent of violations of expected utility theory. For instance, Burgos, Grant and Kajii (1997) model an alternating offers bargaining model where agents preferences exhibit a certainty effect (see Kahneman and Tversky, 1979). Loewenstein and Prelec (1991) present a treatment of choice over time and under risk from a unifying perspective.

${ }^{12}$ Hyperbolic discount functions imply that discount rates decrease over time. For arguments in support of hyperbolic time preferences see for instance Ainslie (1975), Benzion, Rapoport and Yagil (1989), Laibson (1997), Loewenstein and Prelec (1992) and Thaler (1981). Other papers have argued that hyperbolic discounting does not accurately describe time preferences (e.g. Rubinstein, 2000 and Frederick, Loewenstein and O'Donoghue, 2001).

${ }^{13}$ For a thorough review of papers measuring discount factors see Frederick, Loewenstein and O'Donoghue (2001).

${ }^{14}$ This is a private University, and students are selected based on academic achievements at secondary education level and performance in an entry (IQ type) test.

${ }^{15}$ See Becker, DeGroot and Marschak (1964), or Bohm, Linden and Sonnegard (1997). 
of the share of the surplus) in the FIXED treatment (henceforth FXD), or a fall in the value of the chips bargained over in the DISCOUNT treatment (henceforth DSC).

\subsection{Elicited time preferences (BDM)}

In the first stage subjects' preferences were elicited by a modification of the Becker-De GrootMarschak procedure, where a good is substituted for a "bad" (waiting). More precisely, the 40 subjects were told that by agreeing to take part in the experiment each of them was entitled to a prize of 300 monetary units, which however would have to be collected with a delay of X months. They had to write down on special forms the amount of money (limit price) $L P$ they would be willing to pay in order to avoid having to wait $\mathrm{X}$ months to collect their entitlement. The declared limit price would be compared with a randomly ${ }^{17}$ determined asking price. If the latter was lower than the named limit price, then the subject would receive the payment net of the random asking price the next day ${ }^{18}$. If instead the asking price was equal or greater than the declared limit price, the subjects would receive the full sum with one day and $\mathrm{X}$ months delay ${ }^{19}$.

In order to test the constancy of time preferences, subjects were asked to declare two limit prices, one for a delay $\mathrm{X}=1$ month and one with delay $\mathrm{X}=2$ months; consequently, two (possibly distinct) asking prices (one for each version) were drawn. In the end one for the two versions (one or two months) was randomly selected, and payment proceeded accordingly.

As with the usual BDM, here too the dominant strategy for the subjects is to state the true reservation price: the incentive to bid a low price is offset by the fact that the lower the limit price, the less likely it is that the asking price is even lower, resulting in the delayed collection of the prize. Thus, it was possible to measure the subjects monetary evaluation of the time unit X.

The preference elicitation stage was followed by the bargaining phase, in which the same 40 subjects had to negotiate with an anonymous opponent to share some money (additional 300 monetary units). In the bargaining stage negotiations proceeded over two rounds, with the role of first proposer (Bargainer East) and first responder (Bargainer West) assigned randomly, and with subjects of each type sitting in separate rooms.

Subjects exchanged proposals by filling in a paper bargaining form (see appendix) which was carried between rooms by an assistant.

${ }^{16}$ Each monetary unit corresponded to 100 Italian Liras (ITL), which at the time (May 2000) were worth approximately 0.03 GBP.

${ }^{17}$ The asking price was determined by randomly drawing three table tennis balls, one for each digit of the asking price, from three bags, the first of which contained three balls only numbered 0 to 2 (first digit of the asking price) and the other two containing 10 balls each numbered 0 to 9 (for the second an third digits of the asking price). Thus any figure between 000 and 299 had equal probability to be drawn.

${ }^{18}$ In this way all subjects had to come back for payment, whether this was "immediate" or delayed of one or two months. This way possible confounds due to the "hassle" of coming back only in case of either one or two month delay were removed.

19 Instructions clarified that the limit price had no effect on the sum they would receive, but on the likelihood that payment would be brought forward. Comprehension of the instructions was tested before proceeding with the experiment proper, and no problems arose. The full set of the instructions follows after the Appendix. 
Agreement in the first round entailed payment on the following day; agreement in the second round entailed payment with one month delay ${ }^{20}$, whereas failure to reach agreement resulted in no subject receiving any payment. Because the potential existed for delayed agreement, and consequent wait of an additional month, the bargaining form reported for each of the two bargainers involved the one month limit price elicited in the first stage of the experiment. This piece of information was there to convey the cost of delay of the opponent, with the additional advantage to allow for a straightforward comparison with the other two treatments, as explained below.

Subjects received their payment for both stages at the end of the experiment.

\subsection{Fixed cost of delay (FXD) and proportional cost of delay (DSC)}

In both these treatments the task consisted of the bargaining phase only. As in the BDM treatment, 40 subjects were randomly assigned one role (either Bargaining East or Bargainer West) and seated in two different rooms. The bargaining forms used were similar to the one for the BDM treatment, with the idea to replicate in each of the 20 bargaining pairs the costs elicited in stage 1 of the BDM treatment. The way these costs were modelled was however different.

The FXD treatment was based on a fixed cost of delay: agreement in the second round of negotiations resulted in the payment of a fixed fee out of the agreed share. In the FXD treatment a "no bakrupcy rule" established that any agreement in the second round would have to be such that shares were enough to cover both agent's fees in order not to be void (thus resulting in no payment at all). For each bargainer this fee corresponded to each of the one month limit prices observed in the BDM treatment, and bargainers were matched so that each pair of negotiators in the FXD treatment "mirrored" exactly one bargaining pair in the BDM treatment.

Similarly, in the DSC treatment subjects had to divide between them 300 chips, worth initially one monetary unit each. If agreement was reached in the second round, the value of each chip would diminish in some proportion, which was determined so as to correspond to the pair of limit prices of each bargaining pair in the BDM session (see section 5.3 below for the details).

In both FXD and DSC the cost for delayed agreement (fixed or proportional) to both players was reported in the bargaining forms. Subjects were paid privately at the end of the experiment.

${ }^{20}$ In experimental test involving delayed monetary payments the issue of credibility arises. In the experiment of this paper, however, I do not think this aspect was particularly relevant. The trustworthiness of the enterprise was corroborated by the involvement of a senior member of faculty there, who took part in the recruitment of the subjects. The reliability aspects concerning the practicalities as to payment was ensured by telling subjects that for the "immediate" payment (i.e. "tomorrow") I would be available on campus for the whole of the next day. For the "delayed payment" (one and two month, depending on the version extracted) separate envelopes containing cash would have been sent by courier on the specified date to the Students office on Campus - which is very small - where subjects could then collect them. Anonymity was preserved throughout by assigning a random "Personal Identification Code" to each student, who would have to present it in order to collect his/her payment. 


\section{Overview of the results ${ }^{21}$}

The experimental design outlined allows me to address the following two questions:

1. Does time matter in bargaining?

2. Do the standard experimental designs approximate well bargaining in real time?

Clearly, an answer to question 1 can be meaningful only insofar as subjects' preferences are sensitive to the timing of a monetary reward for the time frame chosen ${ }^{22}$. Indeed, this overall turned out to be the case. Specifically, the amount of money subjects were prepared to pay in order to avoid a one month delay in payment was statistically greater than zero. Furthermore, for 23 out of 40 subjects the limit price increased in the "two months" version, and the two observed median of the limit price distributions (10 and 35 monetary units for the "one month" and "two month" versions, respectively) were statistically significant (the Wilcoxon signed rank statistics is -3.182 for a test of equality of medians in the two distributions).

We can now look at whether this time sensitivity is carried over to the bargaining phase, and check which alternative model (fixed or proportional cost of delay) best mimics bargaining over time.

To start with, consider treatment effects on bargaining behaviour ${ }^{23}$, by looking at the first offers/claims in each group. Given the choice of overall resources (300 money units), in a costless environment there are arguably two focal divisions of the surplus, the equal division and the $2 / 3-1 / 3$ split. The former can be viewed as the 'fair' division of the surplus, whereas the latter seems a natural enough partition of the surplus in case the first claimant wishes to exploit his first mover advantage. In actual negotiations these norms did emerge, though in a different way across treatments: although the modal opening claim was the equal split in all treatment, only in the BDM treatment the second norm also emerged, with a sizeable proportion of opening claims $(30 \%)$ at the $2 / 3-1 / 3$ split. More in general, simple visual inspection of the data suggests that overall the distributions of claims/offers are different in the three treatments. (Figure 1).

The median of the three distributions of claims seems unresponsive to treatment: non parametric tests detect no statistically significant differences in the medians (see Appendix), and the unbiased estimate ${ }^{24}$ of the (true) difference in the median offer (or claim) across any two

\footnotetext{
${ }^{21}$ Here I report only part of the statistical tests. The full set of results is in sections 4 and 5 , with further details contained in the appendices.

${ }^{22}$ In pilot experiments I tried a shorther time horizon, setting $\mathrm{X}=1$ week and $\mathrm{X}=2$ weeks. In this case only a very small subset of the subjects displayed any sensitivity at all to time. However, those who did had marked differences in costs between one and two weeks delay. Data are available on request.

${ }^{23}$ The frequencies for offers of Bargainer East can be found in tables and figures in the appendix and section 5 below.

${ }^{24} \mathrm{I}$ use $\hat{\Delta}=\operatorname{med}\left(\mathrm{X}_{\mathrm{i}^{-}} \mathrm{Y}_{\mathrm{j}}\right)$ as an unbiased estimate of the shift parameter $\Delta$ in $\mathrm{G}(\mathrm{x})=\mathrm{F}(\mathrm{x}-\Delta)$, where $\mathrm{F}$ and $\mathrm{G}$ represent the response distributions of subjects in two different treatments. Note that the Wilcoxon test for instance would test the null hypothesis $\mathrm{F}=\mathrm{G}$ against the alternative that one distribution stochastically dominates the other. The estimator $\hat{\Delta}$ is median unbiased (i.e. $\mathrm{E}(\hat{\Delta})=\Delta$, and $\hat{\Delta}$ is distributed symmetrically around $\Delta$, which is the median of the distribution of $\hat{\Delta}$. See Lehmann (1975), chapter 2 .
} 
treatments is zero. However, the variance in the distribution of claims/offers in both the DSC and FXD treatments is higher than in BDM (the Ansari-Bradley statistics are 1.491849 for a test of $\sigma_{\mathrm{FXD}} / \sigma_{\mathrm{BDM}}=1$ against the alternative $\sigma_{\mathrm{FXD}} / \sigma_{\mathrm{BDM}}>1$ and 1.69973 for a test of $\sigma_{\mathrm{DSC}} / \sigma_{\mathrm{BDM}}=1$ against the alternative $\sigma_{\mathrm{DSC}} / \sigma_{\mathrm{BDM}}>1$, with p-values of .07 and .05 , respectively).

More interestingly, the distribution of claims for both DSC and FXD is asymmetric around the median, unlike the one for BDM. That is, in both DSC and FXD the distribution of claims is skewed to the right, revealing a more aggressive behaviour of first movers in this case ${ }^{25}$.
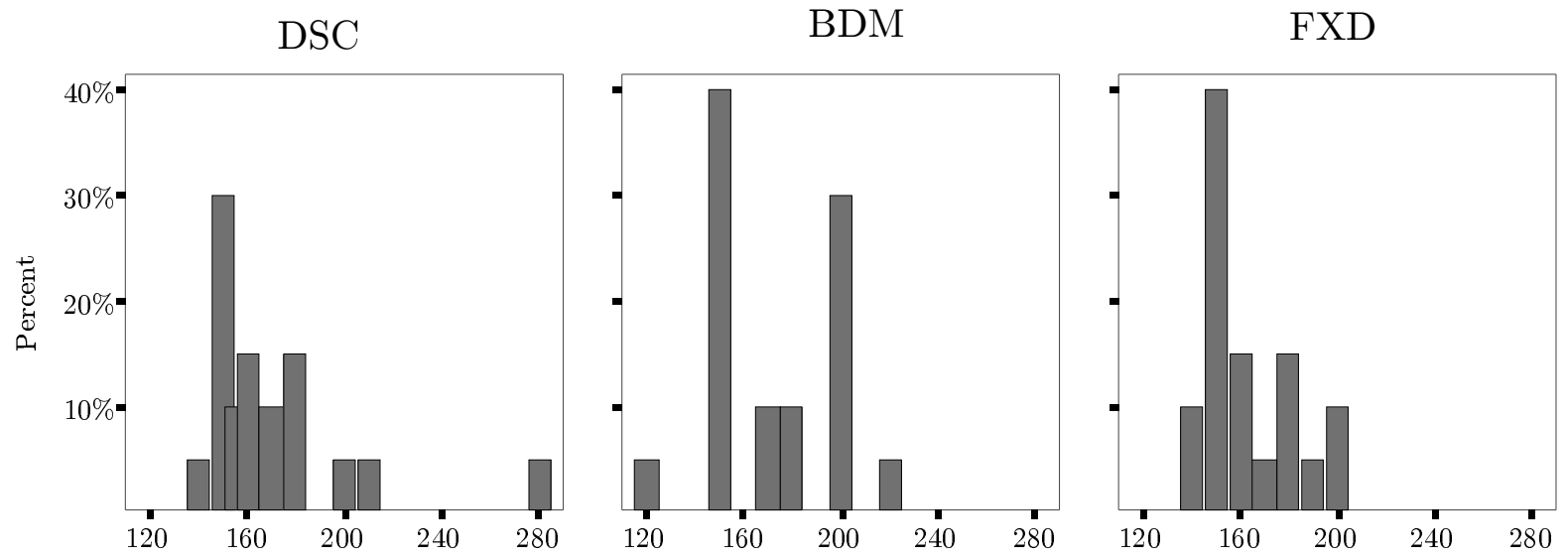

Figure 1: Distribution of Bargainer East's opening claim across treatments

In addition to this, in both DSC and FXD Bargainer East's claim is significantly positively correlated with his opponent's limit price, a result which survives even if the observation relative to the outlier (limit price of 299 for Bargainer West) is removed: Kendall's $\tau$ test for all observations yields a correlation coefficient between East's claim and West's limit price of .446 for FXD (significant at .006, one tailed) and of .463 for DSC (significant at .004, one tailed), whereas for BDM the correlation coefficient is much lower (.154) and anyway not statistically significant. The correlation between East's claim and the limit price differential (limit price of bargainer Eastlimit price of bargainer West) is even stronger (though this time is negative, obviously) for both DSC and FXD, whereas once again in the BDM treatment this correlation is low and not significant ${ }^{26}$.

All in all, these results support the hypothesis of lack of time prominence: although bargainers do prefer their monetary rewards sooner rather than later in an exercise which involves merely

${ }^{25}$ Randles et al. (1981)'s test statistic for distributional symmetry, returns 2.3306 for FXD and 3.0478 for DSC, while only .3409 for BDM. The statistic is distributed as a standard normal under the null hypothesis of symmetric distribution, so that for both FXD and DSC the test rejects the null hypothesis of symmetry against the one sided alternative of right-skewedness at 1\% significance (see Hollander and Wolfe (1999), comment 61). Details of this test are in appendix A.3.3. 
time considerations, embedding the possibility of delayed agreement in a bargaining setup completely focuses attention away from the potential cost of delay: subjects in the BDM experiment seem to discard completely their opponent's cost for time.

On the other hand, when the bargaining framework is completely devoid of time considerations, and the penalty for delayed agreement is directly monetary in nature, subjects do react to the cost of delay, and try to tailor (at least to some extent) their actions to the financial (opportunity) cost of the responder. In this case the claim of first movers is positively correlated to the responders cost of rejection, and even more to the differential between own and opponent's cost. For both these treatments (FXD and DSC), as we know from plenty of experimental evidence (see Roth, 1995), s.p.e. opening claims are hardly observed in practice. However, the conjecture (see Davis and Holt (1993), chapter 5) that in two round bargains subjects' opening claims are smaller than the s.p.e. prediction when the latter is sufficiently high (around at least $80 \%$ of the available surplus), and closer to the s.p.e. when the latter is more "reasonable" (around 50-75\%) is partly contradicted here. As can be seen in the figures below, while it is true that for the highest s.p.e. claims ( 2 cases in the FXD treatment and one case in the DSC case) observed claims show more restraint, in all other cases the observed claim exceeds by far the s.p.e. prediction.
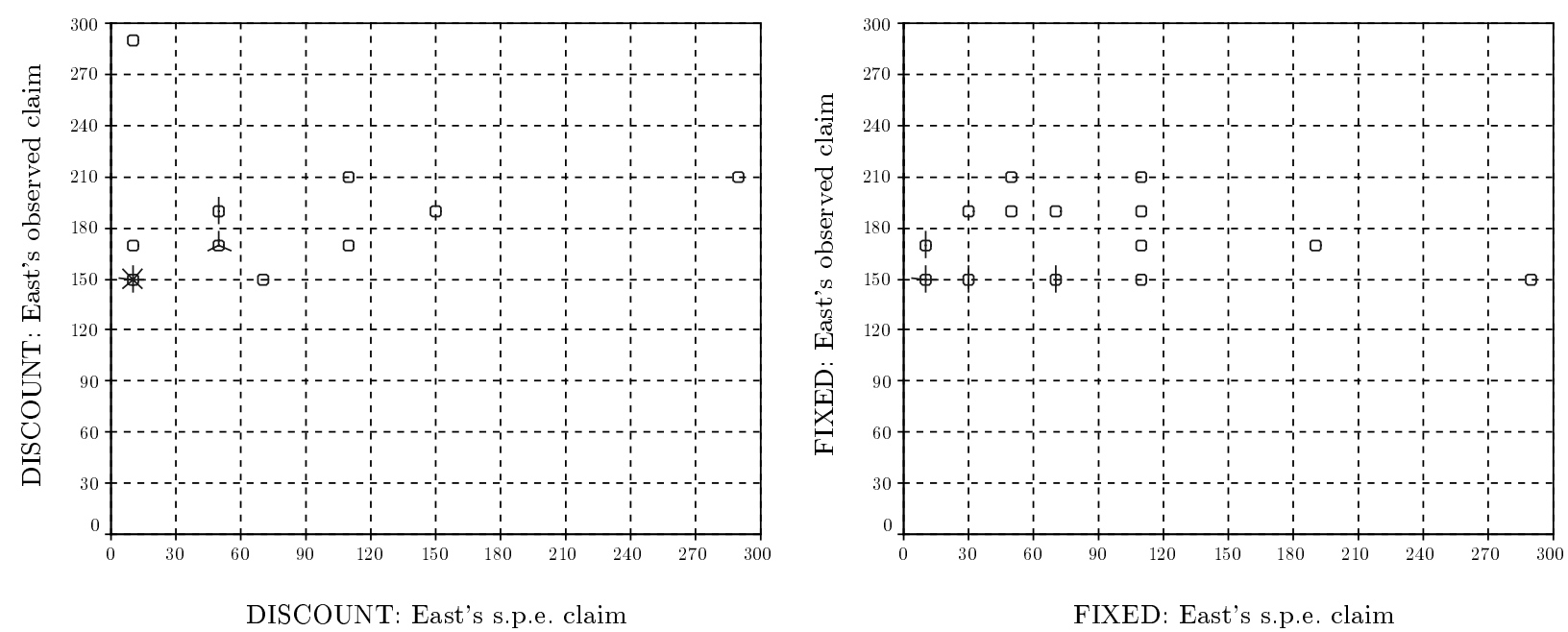

Figure 2: Observed claims and s.p.e. claim in the treatments with monetary costs of delay

What about rejected offers? In bargaining experiments it is not uncommon to observe a significant proportion of players who reject an offer and then make a counterproposal in the following round which, if accepted, yields a lower payoff than if they had accepted the opening offer in the first place ${ }^{27}$. This happens in this experiment, too. However, there are important differences. First of all, whereas in the conventional literature there is a lower percentage of rejection of opening offers (around 15\%), here the percentage of rejected opening claims is considerably higher (50\% in BDM and $35 \%$ in each of FXD and DSC treatments). On the

\footnotetext{
${ }^{26}$ All these results are detailed in section 5 and in the appendices.
} 
contrary, the percentage of "irrational" lower counterclaims is much lower (30\% in BDM, $28.6 \%$ in FXD, and none DSC), and at least in the BDM it is also difficult to argue that these are indeed irrational offers once it is no longer clear that subjects do take costs of delay into account when bargaining. I conjecture that part of the more aggressive behaviour displayed by subjects in this experiment as compared to previous literature is due to the fact that subjects were playing one time only.

In the BDM treatment, second round claims present the same pattern observed in the first round is repeated, with a concentration of offers on the two norms. Incidentally, these counteroffers are not always accepted; indeed the BDM treatment was the most fractious, with three sets of negotiations ending in disagreement, and agents seemed to resent what they perceived as "low" offers, as time cost were not taken into account.

For both the other treatments (FXD and DSC) it is possible to compute the subgame perfect equilibrium claims in the second round (off the equilibrium path; see section 5 below). In both FXD and DSC responders move boldly away from the equal division (which is never offered) and embrace a $2 / 3-1 / 3$ convention. The results are analysed in detail in the following sections.

\section{Time preferences}

Subject's evaluation of time was elicited by means of a modified BDM procedure as described above (see instructions in the appendix).

Figure 2 reports the scatterplot for one month and two months limit prices. For 2 individuals preference reversal occurred (points lying below the diagonal). Although most observations are concentrated around the bottom left corner of the scatter, subjects exhibit a pronounced variability in their time prefeences, which is described in Figure 4. Here negative, positive and no change between one month and two months limit prices are indicated with "_ ", "+" and "=", respectively. The column denoted by "=(0)" refers to limit prices which did not change at all over time; the column denoted by "=(1)" refers to limit prices which were equal to just 1 for "one month", and did not change in the "two month" condition.

For 6 individuals preferences appear to be completely insensitive to the time horizon chosen (i.e. their limit price is always zero - these are the cases in the $=(0)$ column in Figure 4); further 9 of them are sensitive to the first delay (i.e. one month), but not to the second (i.e., the difference

between two months and one month limit price is zero - cases in columns $=(1)$ and $=$ in Figure $4)$.

${ }^{27}$ See e.g. Roth (1995). 


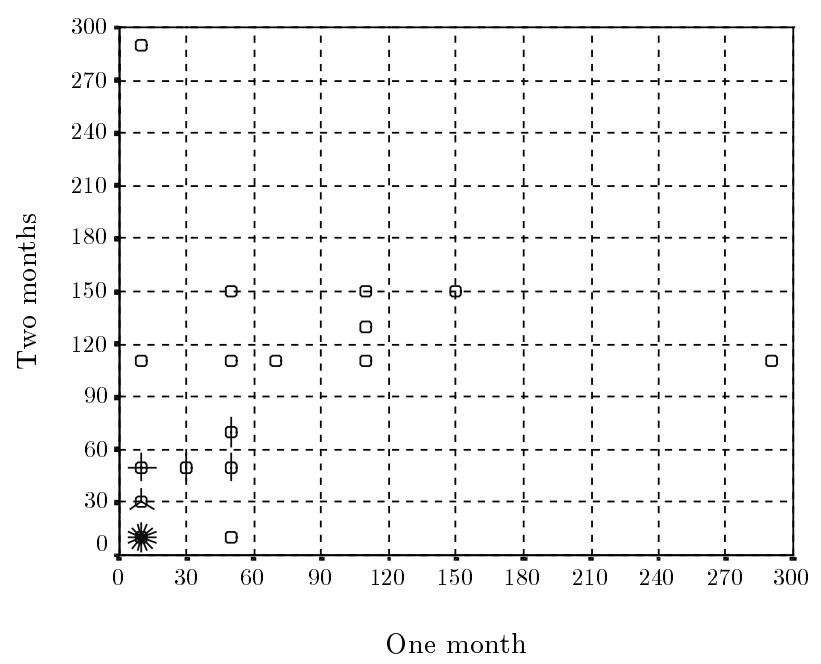

Figure 3: limit prices for all observations

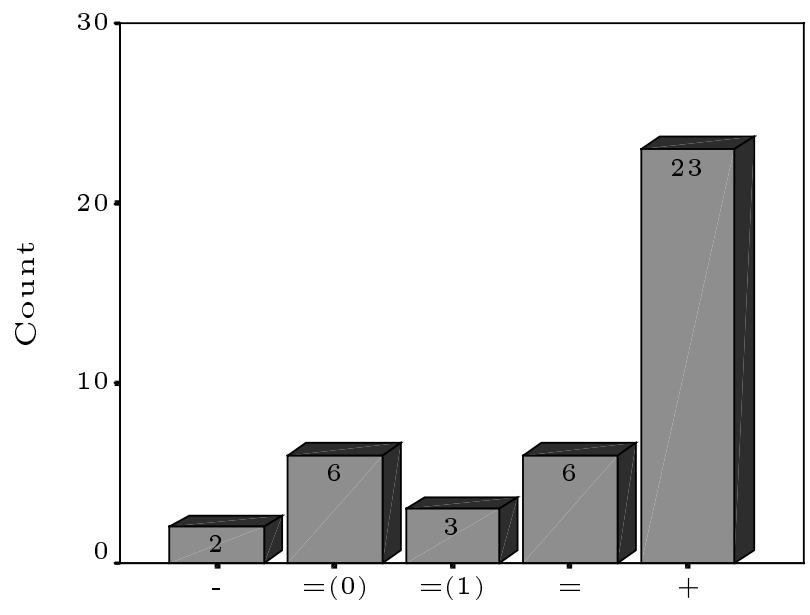

Change in limit prices

Figure 4: Qualitative changes in limit prices

Descriptive statistics are reported in Table 1 below.

\begin{tabular}{|c|c|c|c|}
\hline & & One month & Two months \\
\hline $\bar{N}$ & & 40 & 40 \\
\hline Mean & & 32.88 & 50.88 \\
\hline Median & & 10.00 & 35.00 \\
\hline Mode & & 0 & 0,50 \\
\hline Std. Dev. & & 55.82 & 61.39 \\
\hline Minimum & & 0 & 0 \\
\hline Maximum & & 299 & 299 \\
\hline \multirow[t]{3}{*}{ Percentiles } & 25 & .25 & 3.25 \\
\hline & 50 & 10.00 & 35.00 \\
\hline & 75 & 50.00 & 90.00 \\
\hline
\end{tabular}

Table 1: Descriptive statistics for observed limit prices

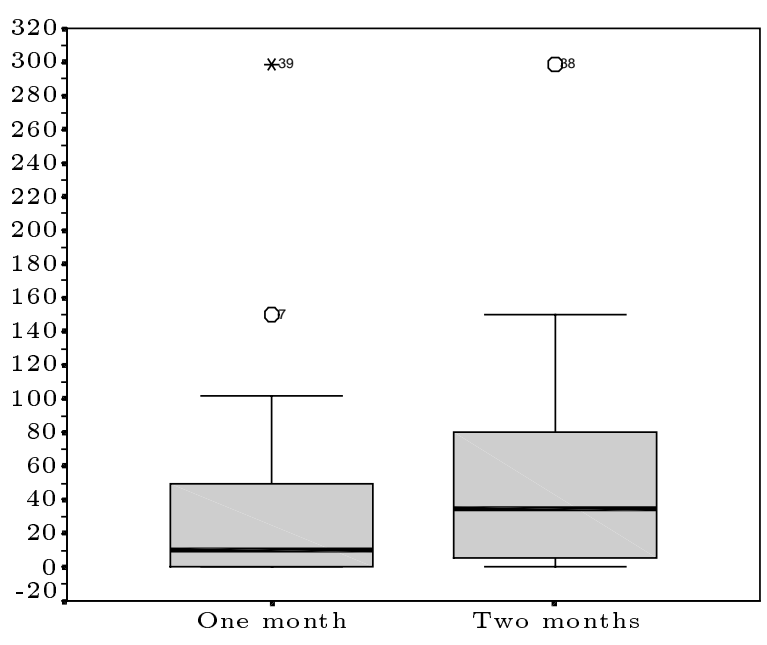

Figure 5: limit price distributions (the thick line represent the median)

The distribution and dispersion of one month and two month limit prices is visualised in Figure 5, which reports quartiles for the two sets of limit prices, where the thick lines identify 
the median ${ }^{28}$. A Wilcoxon test performed on the data is consistent with the hypothesis that the two month (TM) limit price distribution first order stochastically dominates the one month $(\mathrm{OM})$ limit price distribution, that is, TM has a statistically significant higher median than OM. Note that this effect is enhanced if we exclude from the analysis the cases which exibhited preference reversal (indicated in parenthesis in Table 2).

\begin{tabular}{|c|c|c|c|c|}
\hline & & $\mathrm{N}$ & Mean Rank & sum of ranks \\
\hline \multirow{4}{*}{ TM-OM } & Neg. Ranks ${ }^{a}$ & $2(0)$ & $22.25(0)$ & $44.50(0)$ \\
\hline & Pos. Ranks ${ }^{b}$ & 23 & 12.20 (12) & $280.50(276)$ \\
\hline & Ties $^{c}$ & 15 & & \\
\hline & Total & $40(38)$ & & \\
\hline
\end{tabular}

Test Statistics ${ }^{\mathrm{a}, \mathrm{b}}$

\begin{tabular}{|l|l|}
\hline & TM-OM \\
\hline$Z$ & $-3.182(-4.209)$ \\
\hline Asymp. Sig. (2-tailed) & $.001(.000)$ \\
\hline a & Based on negative ranks \\
b & Wilcoxon Signed Ranks Test \\
\hline
\end{tabular}

Table 2: Test for equality of medians between one month and two month limit prices.

All in all, then, the results above support the hypothesis that subjects were sensitive to the time frame chosen.

\section{Bargaining behaviour}

As a preliminary, note that in the three types of bargain the subgame perfect equilibrium (henceforth s.p.e.) offers differ. Assuming linear utility for money, in the DSC treatment, solving backwards, if the game were to reach the second stage, Bargainer West (player 2) would claim the whole surplus, i.e. all of the 300 chips bargained over. Letting $\delta_{\mathrm{W}}$ denote the amount that each chip is worth to him in the second round, the most bargainer East (player 1) can claim in the first round is $300-300 \delta_{\mathrm{W}}=\left(1-\delta_{\mathrm{W}}\right) 300$.

On the other hand, in the FXD treatment in second round player West has to ensure that player 1 receives an amount sufficient to cover his second period tax, as because of the "nobankruptcy constraint" any agreement which failed to cover both player's cost would be void. Additionally, bargainer West would have to cover his own fee, too. Consequently, West's payoff in the second round would be $300-\mathrm{LP}_{\mathrm{E}}-\mathrm{LP}_{\mathrm{W}}$, which then is what player East would have to concede in the first round, retaining for himself $\mathrm{LP}_{\mathrm{E}}+\mathrm{LP}_{\mathrm{W}}$.

${ }^{28}$ Whiskers at the two ends of each box show the distance from the end of the box to the largest and smallest value within 1.5 box length from either end of the box. Outliers are displayed separately. 
Thus the main difference between the s.p.e. first offers in the DSC and FXD treatment is that under DSC the discount treatment first offers depend only on the responder's cost of delay, whereas in the FXD case equilibrium first offers depend on both player's cost of delay.

Proportional costs of delay (discount factors) in the DSC treatment were constructed quite crudely from the one month limit prices elicited from subjects via the BDM procedure as $\delta_{i}=\frac{300-L P_{i B D M}}{300}$, where $\mathrm{LP}_{\mathrm{iBDM}}$ is the limit price of the "mirror" bargainer West in the BDM treatment. This way of deriving discount factors may under-estimate the corresponding actual discount factors for the subject in the BDM treatment, especially if the utility function is not linear in money. However the only purpose of proportional discounting in this paper is to evaluate whether it constitutes the appropriate frame to describe the essential features of negotiations over real time. What is crucial for my results is that both the "correct" discount factor underlying the subjects' preferences and my own crude representation of it are some function of the limit prices - a mild requirement. This is enough to allow a correct interpretation of the various non-parametric tests ${ }^{29}$ my analysis relies on, for which the only relevant information is rank. Consequently, these tests are invariant to any order preserving transformation of the variable of interest.

With this caveat in mind, it is possible to express the s.p.e. opening offer in the discount case as $\left(1-\delta_{i}\right) 300=\left(1-\frac{300-L P_{i B D M}}{300}\right) 300=L P_{i B D M}$. The table below reports the figures used in this conversion between limit prices and discount factors used in the experiment ${ }^{30}$.

\begin{tabular}{|l|l|l|l|l|l|l|l|l|l|l|l|l|l|l|l|l|l|}
\hline $\mathrm{LP}_{\text {іврм }}$ & 0 & 1 & 9 & 10 & 12 & 13 & 20 & 30 & 40 & 45 & 50 & 60 & 100 & 101 & 102 & 150 & 299 \\
\hline$\delta_{\mathrm{i}}$ & 1 & .99 & .97 & .97 & .96 & .96 & .93 & .90 & .87 & .85 & .83 & .80 & .66 & .66 & .66 & .50 & 0 \\
\hline
\end{tabular}

Table 3: Conversion between elicited limit prices $\left(\mathrm{LP}_{\mathrm{iBDM}}\right)$ and discount factors $\left(\delta_{\mathrm{i}}\right)$. All numbers in hundreds of ITL.

In the experiments, in both treatments East's claims have wildly exceeded the s.p.e. predictions. Similarly for West's claims in the second round. Significantly, though, none of the second period offers were at the equal split level. This seems to show that as long as some focal point/convention other than the equal split is available it is used as anchor and sustains more aggressive behaviour. Subgame perfect equilibrium strategies are described in Table 4.

\footnotetext{
${ }^{29}$ See also footnote 35 below.

${ }^{30}$ Because of roundings, in some cases the same discount factor may correspond to slightly different limit prices. However such discrepancies are so small that this does not constitute a problem for the analysis.
} 


\begin{tabular}{|c|c|c|c|}
\hline & & $\begin{array}{l}\text { Fixed cost } \\
\text { (Proposal is an amount of money) }\end{array}$ & $\begin{array}{l}\text { Proportional discounting } \\
\text { (Proposal is an amount of chips) }\end{array}$ \\
\hline $\begin{array}{l}\text { Bargainer } \\
\text { East }\end{array}$ & $\begin{array}{l}\text { Proposes } \\
\text { Accepts } \\
\text { Rejects }\end{array}$ & $\begin{array}{l}\left(L P_{E}+L P_{W} ; 300-\left(L P_{E}+L P_{W}\right)\right) \text { if } \\
L P_{E}+L P_{W} \leq 300 ; \\
\text { claims all surplus otherwise } \\
x \geq L P_{E} \\
x<L P_{E}\end{array}$ & $\begin{array}{l}\left(\left(1-\delta_{W}\right) 300 ; \delta_{W} 300\right)=\left(L P_{W} ; 300-L P_{W}\right) \\
x \geq 0 \\
x<0\end{array}$ \\
\hline $\begin{array}{l}\text { Bargainer } \\
\text { West }\end{array}$ & $\begin{array}{l}\text { Proposes } \\
\text { Accepts } \\
\text { Rejects }\end{array}$ & $\begin{array}{l}\left(L P_{E} ; 300-L P_{E}\right) \text { if } L_{\mathrm{E}}+\mathrm{LP}_{\mathrm{W}} \leq 300 ; \\
\text { claims all surplus otherwise } \\
x \geq 300-\left(L P_{E}+L P_{W}\right) \\
x<300-\left(L P_{E}+L P_{W}\right) \\
\text { Note that W's s.p.e. payoff in the second round } \\
\text { (off the equilibrium path) is } 300-L P_{W}-L P_{E}\end{array}$ & $\begin{array}{l}(0 ; 300) \\
x \geq \delta_{W} 300=300-L P_{W} \\
x<\delta_{W} 300=300-L P_{W}\end{array}$ \\
\hline
\end{tabular}

Table 4: Subgame perfect equilibrium strategies in FXD and DSC.

Bargaining behaviour for each of the three treatments is analysed in more detail in the sections that follow.

\subsection{Elicited time preferences (BDM)}

The frequencies are visualised in Figure 6. The first thing to observe is that although the modal claim is 150, there is another "mass point" at 200. Furthermore, more than $55 \%$ of the offers lie above the sample mode, as well as the sample median (which is 170).

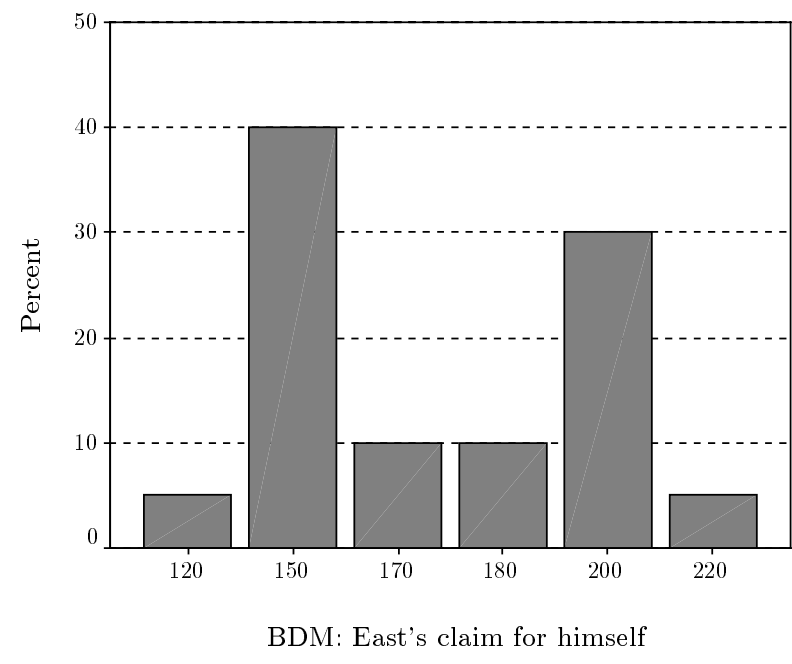

Figure 6: Opening claims in the BDM treatment

So, it seems that as a heuristic subjects used the either a fifty-fifty or a $2 / 3-1 / 3$ convention ${ }^{31}$.

${ }^{31}$ The choice of convention may depend on the opponent limit prices, however the evidence in this respect is weak. Specifically, the average limit price for bargainer West is 36.83 in correspondence of the 200 mark, and either 13.29 or 49 in correspondence of the 150 claim, depending on whether the 
But which of these offers are accepted? Below is the distribution of successful and rejected proposals. Not surprisingly, the highest offers get rejected.

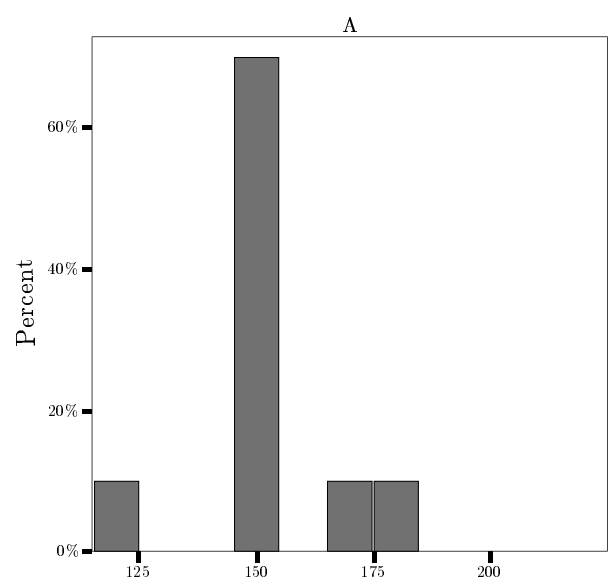

BDM: East's claim for himself

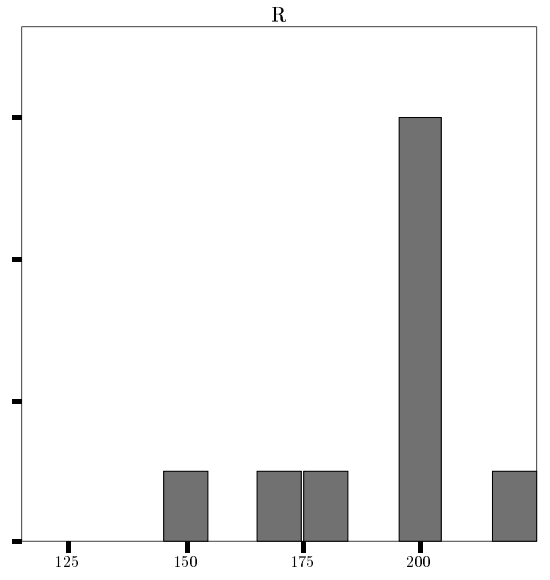

BDM: East's claim for himself

Figure 7: Accepted and rejected opening claims in the BDM treatment

A Wilcoxon test shows a clear difference in the medians of the two distributions $(\alpha<1 \%$ one tailed $\left.{ }^{32}\right)$. However, there is now a significant negative correlation of rejected offers with the rejector's limit price, as can be seen from the table below. This reinforces the conclusions drawn above that limit prices are not taken into account in the bargaining phase of the BDM treatment: the responders with the higher limit prices seem oblivious of their "condition" and reject also pretty "central" offers, as visualised in Figure 7 above.

\begin{tabular}{|c|c|c|c|c|c|}
\hline & & & $\begin{array}{l}\text { Limit price for } \\
\text { bargainer } \\
\text { west }\end{array}$ & $\begin{array}{l}\text { Limit price for } \\
\text { bargainer } \\
\text { East }\end{array}$ & $\begin{array}{c}\text { Limit price } \\
\text { differential (i.e. } \\
\text { East-West) }\end{array}$ \\
\hline \multirow{6}{*}{ East's claim } & \multirow{3}{*}{ A } & Cor. Coeff. & .287 & -.036 & -.246 \\
\hline & & Sig. (1-tailed) & .154 & .453 & .186 \\
\hline & & $\mathrm{N}$ & 10 & 10 & 10 \\
\hline & \multirow{3}{*}{$\mathrm{R}$} & Cor. Coeff. & $.479\left(^{*}\right)$ & -.117 & $-.495\left(^{*}\right)$ \\
\hline & & Sig. (1-tailed) & .040 & .337 & .033 \\
\hline & & $\mathrm{N}$ & 10 & 10 & 10 \\
\hline
\end{tabular}

Table 5: Correlations based on Kendall's $\tau$ test - accepted vs. rejected offers

observation related to the only subject with limit price 299 is excluded or not from the analysis. So, while dropping the outlier seems to suggest some rule of thumb for the choice of convention, there is not enough evidence to warrant the deletion of this observation from the data-set. Furthermore, remember that at any rate there is no evidence of correlation between opponents' limit prices and own offers.

${ }^{32}$ See appendix. 
As one would expect, all the counteroffers in the second round yield bargainer East less than his initial claim. Furthermore, indifference to the opponent's limit prices persists, and similarly to East's claims in the second round, West's offers turn out to be uncorrelated with the opponent's limit prices (Kendall's $\tau$ test is not significant - see appendix).

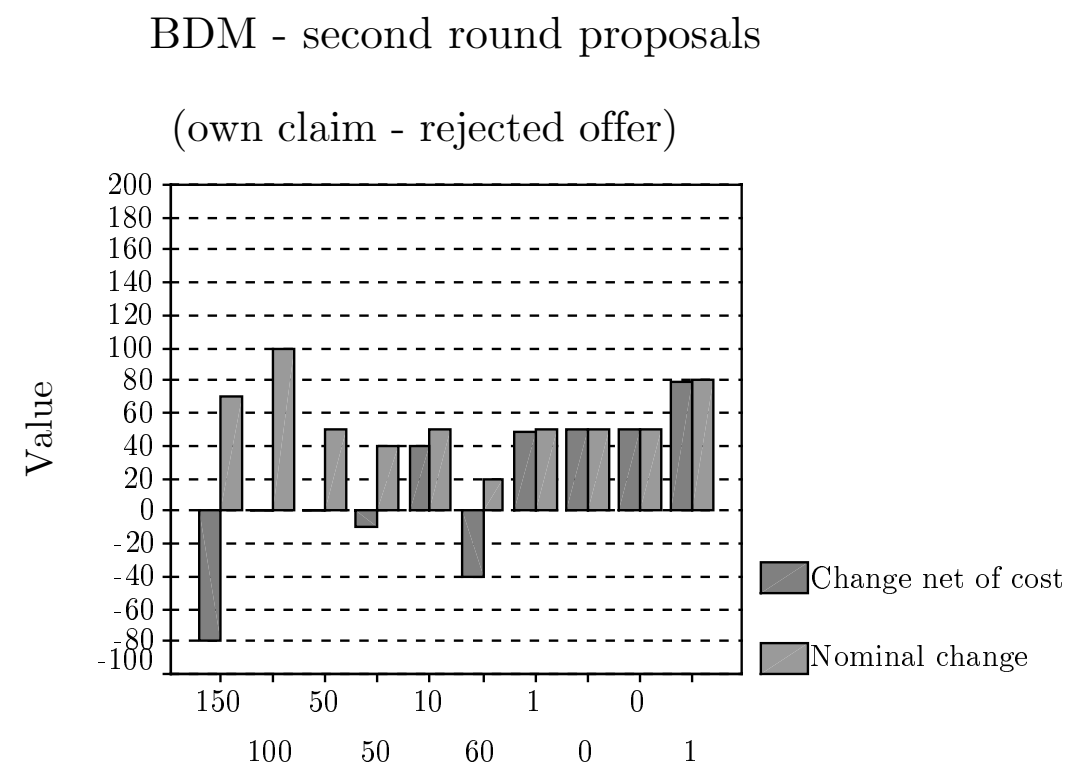

Limit price for bargainer west

Figure 8: Second round claims and payoffs

Figure 8 visualises the differences between Bargainer West's the own claim in the second round and the rejected offer in the previous period are represented.

As anticipated in section 5, for three subjects counteroffers in the second round did give the proposer more than the rejected offer in terms of monetary payoff, but a smaller "utility" once the limit price is taken into account. While all monetary differences are strictly positive and of considerable value, once the cost of waiting is taken into account $50 \%$ of these differences become either zero or negative (and considerably so). Interestingly, this happens quite independently of the rejector's limit price. Furthermore, Figure 9 underlines the predilection for two norms, the fifty-fifty split and the $2 / 3-1 / 3$ division.

As mentioned above, of all treatments, this was the most fractious: $50 \%$ of first offers were initially rejected, and three of the negotiations ended with no agreement, with both bargainers obtaining a null payoff. 


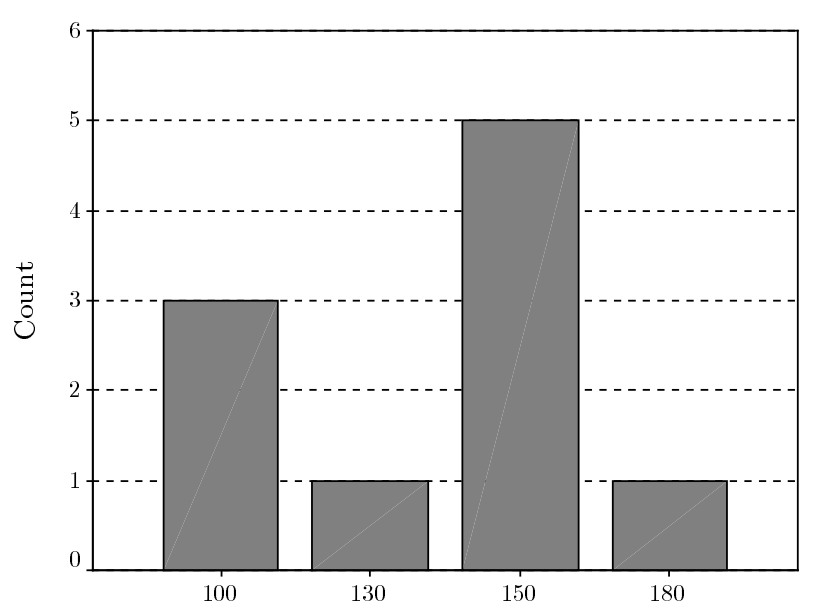

BDM: West's offer in the second round

Figure 9: Second round offers

These results suggest that, although subjects did show a sensitivity to time (i.e. when confronted with a task which involves purely time, subjects do notice), when the principal task is such that time is only one of the relevant features involved, it seems not to matter. There is not a great deal of dispersion in the initial offers (as compared to the other treatments, as we will see below), which are uncorrelated to limit prices, and agents concentrate their proposals around two conventions, 50/50 and $2 / 3-1 / 3$.

The rejected offers are indeed correlated with respondent's limit prices: however, the fact that they are rejected shows that responders do not recognise the role of time. This is further reinforced by two facts:

- counteroffers follow a similar pattern to those of first movers: proposals are uncorrelated with limit prices, are not very dispersed and concentrate around the two conventions.

- In monetary terms counteroffer are advantageous to bargainer West; however, they become negative if limit prices are taken into account.

\subsection{Fixed cost of rejection (FXD)}

In this treatment the mode and median for the distribution of bargainer East's claim coincide at 150 (i.e. equal split). However, while the average opening claim for the first two quartiles in the distribution is 145 , the claim for the second half is much higher at 178 . Moreover, this distribution has a narrower support than that for the BDM, as depicted in Figure 10: 


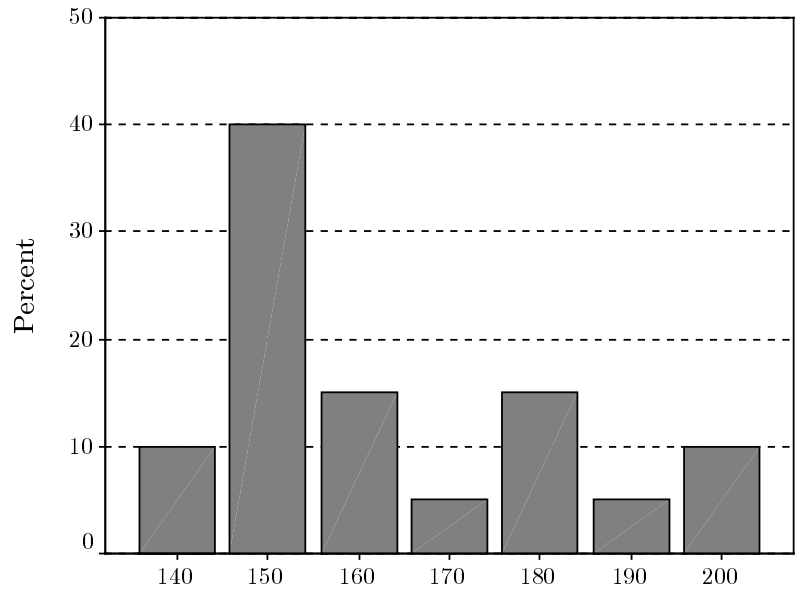

FIXED: East's claim for himself

Figure 10: Opening claims in the FXD treatment

The first thing to note is that, as in the BDM treatment, a considerable proportion (40\%) of the claims are at the equal split division; however, although $50 \%$ of the claims are in excess of the equal split, the second convention observed in the BDM treatment (i.e. the $2 / 3-1 / 3$ partition) is no longer focal. This comes as no surprise once the relationship with the opponent's cost of rejection is inspected: as observed in section 3, opening offers are significantly positively correlated to responder's cost of rejecting an offer, and a nonparametric test of distributional symmetry shows that both distributions (East's claims and West's cost of rejection) are skewed to the right ${ }^{33}$.

Consider now rejections. As above, the highest offers end up being rejected, and there is a significant difference in the medians of the accepted and rejected proposals.

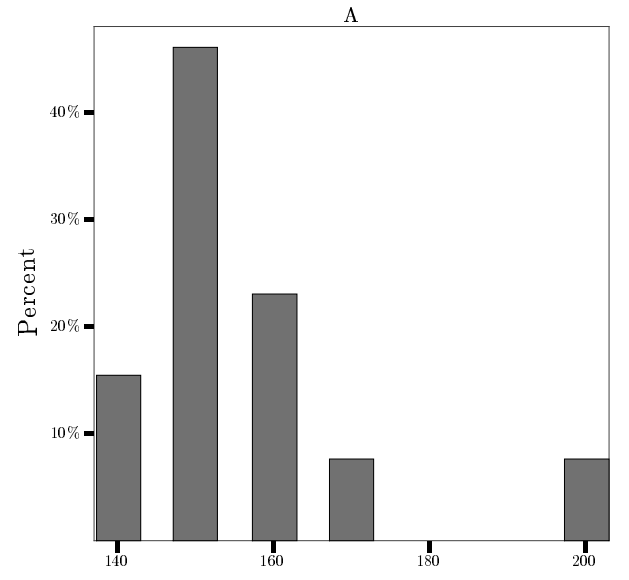

FIXED: East's claim for himself

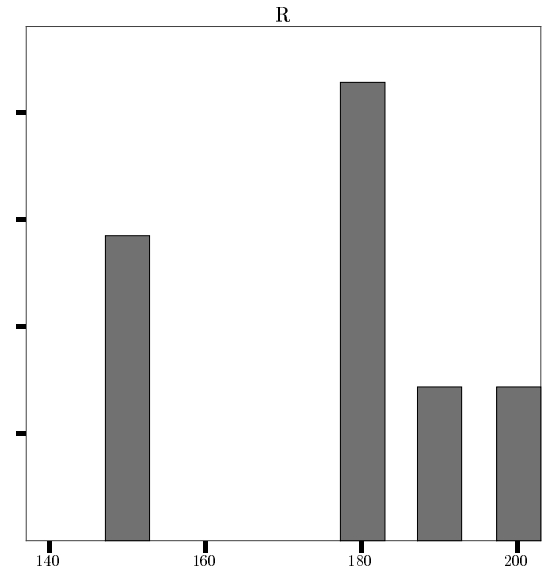

FIXED: East's claim for himself

Figure 11: Accepted and rejected opening claims in the FXD treatment

\footnotetext{
${ }^{33}$ See appendix A.3.3.
} 
Although less pronounced than in the BDM treatment, here as well there is a significant difference between the median accepted and rejected proposals (Wilcoxon signed rank test, $\alpha<5 \%$ - see appendix). Furthermore, only seven proposals (rather than 10 in the BDM treatment) are rejected. Counteroffers appear to be rational insofar as they yield the first mover less than he originally claimed for. Moreover, only two out of the seven rejected offers yield a non-positive monetary payoff to the proposers, and no bargain end in disagreement (see Figure 12).

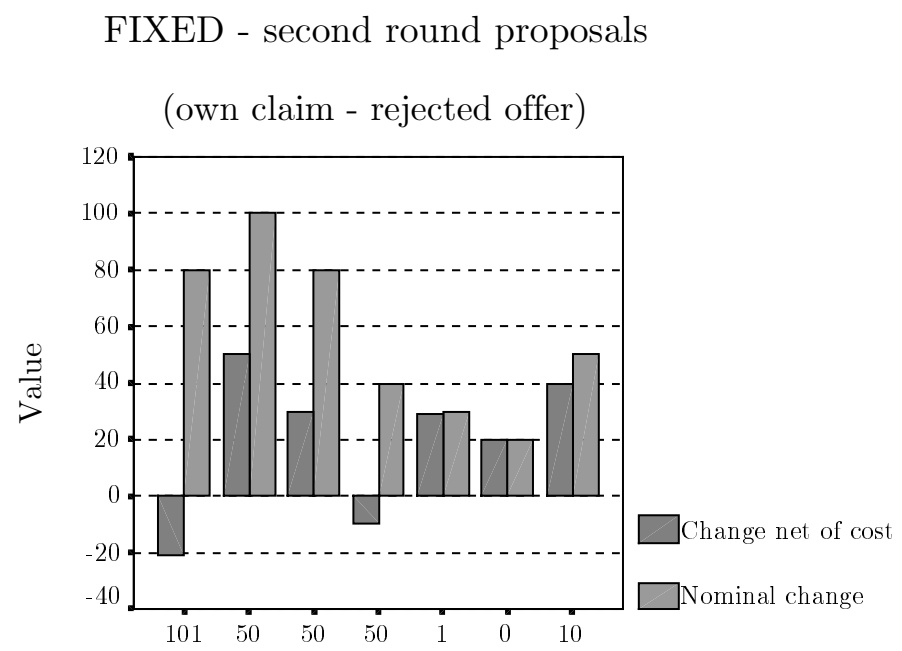

Limit price for bargainer west

Figure 12: Second round claims and payoffs

Counteroffers exhibit a less 'recognisable' pattern as compared to the BDM case, as shown in Figure 13. Responders seem very aware of the weakness which derives from their own cost of delay, and apparently fail to realise that there is a role reversal. Incidentally, during postexperimental debriefings, in the mains those subjects who were selected to be responders in the first round (i.e. bargainers West) felt that they were at a disadvantage in negotiations because of their role as responders.

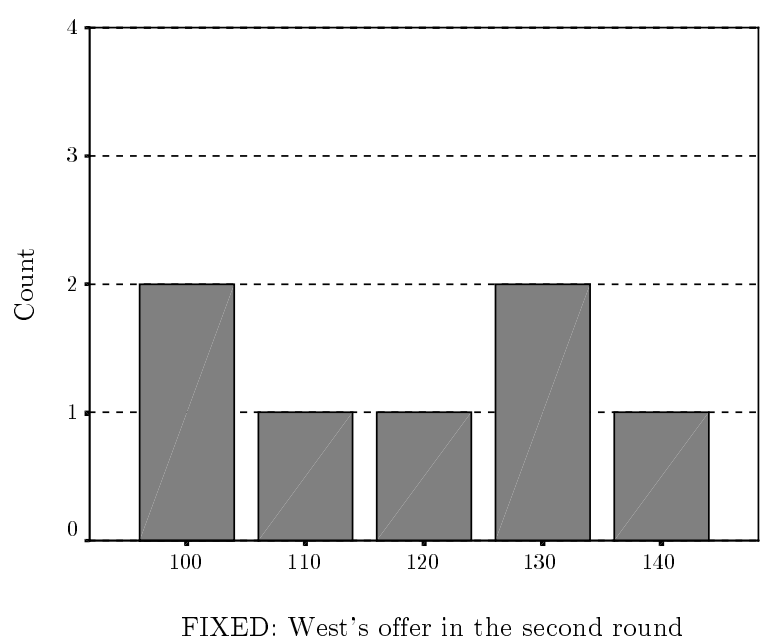

Figure 13: Second round offers 
This anxiety about own cost of disagreement tallies well with the experimental behaviour. As mentioned above, proposers in the second round (bargainers West) consistently offered to their opponent (bargainer East) less than what they had claimed in the previous round. The differential turns out to be significantly negatively correlated with bargainers West's own cost of disagreement ${ }^{34}$, as reported in Table 6

\begin{tabular}{|l|l|l|l|}
\hline \multicolumn{2}{|c|}{} & $\begin{array}{l}\text { Cost for bar- } \\
\text { gainer West }\end{array}$ & $\begin{array}{l}\text { Cost for bar- } \\
\text { gainer East }\end{array}$ \\
\hline \multirow{2}{*}{$\begin{array}{l}\text { Difference between West's } \\
\text { offer to East and East's claim } \\
\text { in the previous round }\end{array}$} & $\begin{array}{l}\text { Correlation } \\
\text { Coefficient }\end{array}$ & $-.685\left(^{*}\right)$ & -.065 \\
\cline { 2 - 4 } & Sig. (1-tailed) & .020 & .429 \\
\cline { 2 - 4 } & $\mathrm{N}$ & 7 & 7 \\
\hline$*$ Correlation is significant at the .05 level (1-tailed).
\end{tabular}

Table 6: Correlations based on Kendall's $\tau$ test

The analysis above seems to suggest that a fixed cost of disagreement is very clearly perceived by the subjects: First movers' offer are significantly negatively correlated with responders' costs of disagreement, and the correlation coefficient is high (in excess of .4 in absolute value). The effect of costs of delay is significant in offers in the second round too. Only, in this case subjects perceive their own cost as a source of reduced bargaining power, and their proposals are less aggressive the higher their own cost of disagreement.

\subsection{Discount}

The support of the distribution of initial claims (which is skewed to the right) in this treatment is much larger than for the other two cases; as shown in appendix A.3.2 this distribution is more dispersed than for the BDM treatment, whereas non statistically significant differences can be detected with respect to the FXD treatment.

Although the equal split constitutes the modal claim (and accounts for $40 \%$ of the cases), both the median and the average initial claims are higher, at 160 and 170, respectively. Moreover, $60 \%$ of claims do not correspond to any established norm; once again, the key to explain this pattern of offers is the positive correlation with the opponent's cost of rejecting an offer (see appendix A.3.4). The frequencies are represented in Figure 14.

\footnotetext{
${ }^{34}$ Recall that no such behaviour is observed in the BDM treatment.
} 


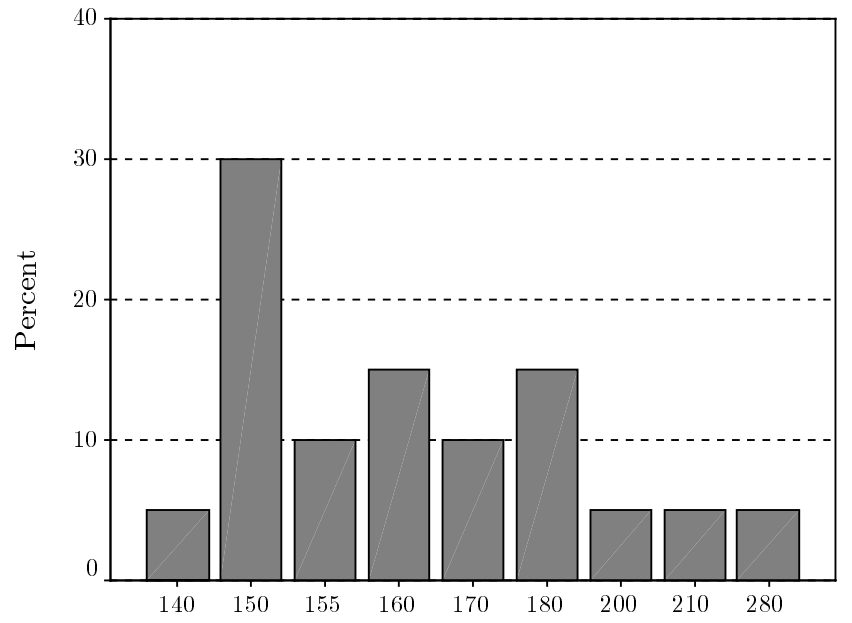

DISCOUNT: East's claim for himself

Figure 14: Opening claims in the DSC treatment

Consider now the responder's behaviour. In this treatment the median of rejected offers is not much higher than of the accepted ones, as shown in Figure 15.

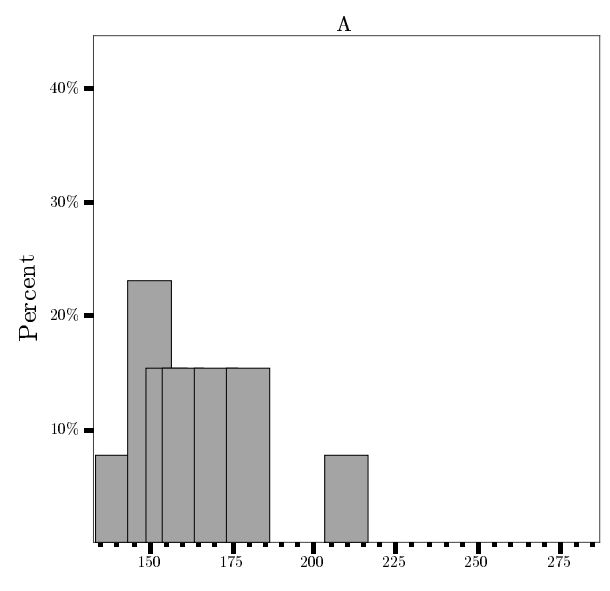

DISCOUNT: East's claim for himself

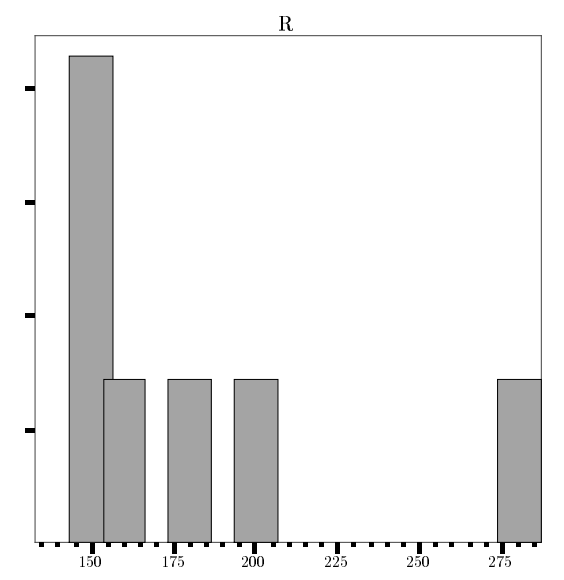

DISCOUNT: East's claim for himself

Figure 15: Accepted and rejected opening claims in the DSC treatment

A Wilcoxon signed rank test indeed that the two medians do not differ statistically in a significant way (with $\alpha<1 \%$ ). Regarding counteroffers, they are "rational", in the sense that they yield a discounted payoff which is in excess of the rejected offer. Unlike the other two treatments, here payoffs in case of agreement are (by construction) always non-negative.

As in the FXD treatment (and to less extent in the BDM treatment), the $2 / 3-1 / 3$ division seem to attract most counteroffers (see Figure 16), and these counteroffers are always "rational", in the sense that they always yield to the proposer a higher payoff than if he had accepted the opening offer (Figure 17). 


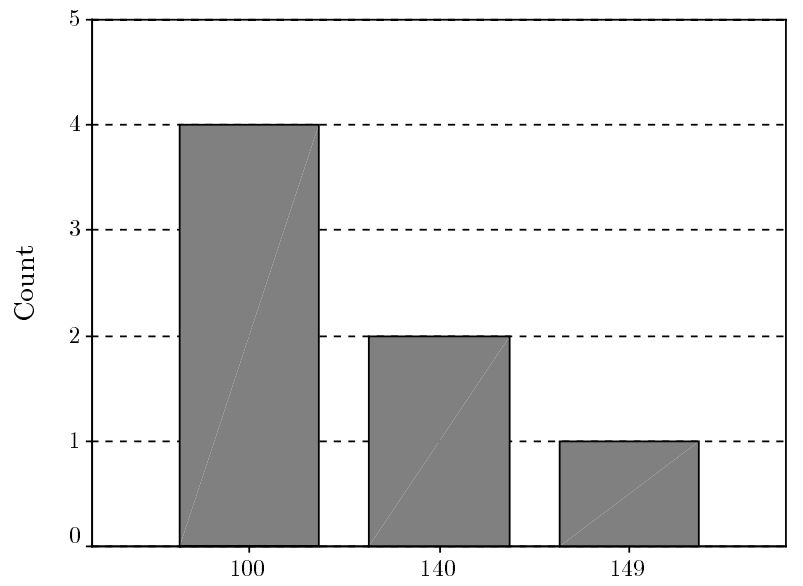

DISCOUNT: West's offer in the second round

Figure 16: Second round offers

Finally, as in all other treatments, bargainer West's offer is uncorrelated to any of the limit prices $^{35}$.

DISCOUNT - second round propsals

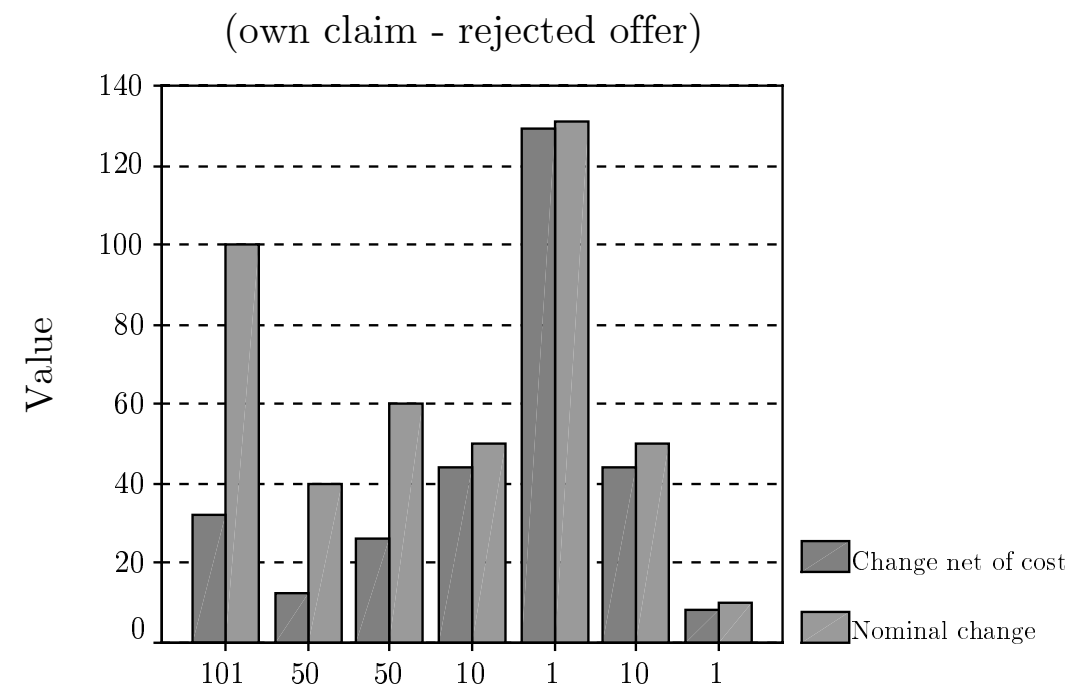

Limit price for bargainer west

Figure 17: Second round claims and payoffs

The analysis above seem to suggest that a discounted cost of disagreement is clearly perceived by the subjects, which take it into account when making their offers. On the other hand, responders are more aware of their own vulnerability in the first round due to their

35 Note that obviously, being Kendall's $\tau$ a non-parametric test, the result is invariant to considering the discount factor rather than the limit price (in level). This is why in this analysis the precise way discount factors are derived from limit prices is not crucial. 
own cost of disagreement. This effect persists in the second round, where counteroffers are negatively correlated to their own cost of disagreement.

\section{Discussion}

One point that is worth stressing is that, regardless of the specific discount factors underlying subjects' preferences, the fact that delay is imposed in the same way in both stages of the BDM treatment implies that there is no reason to expect a different evaluation of monetary outcomes in the two phases as far as time attitudes are concerned ${ }^{36}$. Thus, it seems reasonable to attribute any differences in the attitude towards time to the superimposition of the bargaining structure.

The upshot of this analysis is therefore that even if subjects do show that they are sensitive to the timing of a monetary reward, superimposing another task (bargaining) introduces a distractor which focuses attention away from time considerations altogether.

This is all the more striking when one considers that the negotiations in which subjects were involved were very stylised, and were still on monetary outcomes. On the other hand, when the costs of disagreement are explicitly expressed in monetary terms, they do affect bargaining behaviour. In terms of real life negotiations, this seems to suggest that although there are instances where the costs associated to delays are clearly perceived, in others additional interests may completely override the time dimension.

Of course, these results do not have the pretense to undermine the vast and rich noncooperative bargaining theory based on time preferences ${ }^{37}$, though they hint that there is room and scope for reinterpretation of what 'time preferences' really mean in those models.

36 One possible exception could be wealth effects, as in the second stage the subjects were potentially richer (because of the 300 monetary units gained in the first stage). However the "aggressiveness" of the opening claims during bargaining may be evidence enough to show thus such wealth effects, if present, were not too strong.

${ }^{37}$ Nor would I want to, as most of my contributions are in this field! 


\section{Appendices}

\section{A Statistical tests}

\section{A.1 Limit prices}

\section{A.1.1 Symmetry}

The test performed is based on Palomino et al. (1981). It consists in classifying all possible subset of size three of observations coming from each sample as either right (if the average of the observations is greater than the median) or left (if the reverse is true). The difference $\mathrm{T}$ between the number of right and left triples is then found. An estimate of the variance, $\sigma_{\mathrm{T}}$ is then computed, and the statistic $\mathrm{T} / V_{\sigma_{\mathrm{T}}}$ is distributed as a standard normal under the null hypothesis of symmetric distribution. The results are reported below:

\begin{tabular}{|l|l|l|l|}
\hline & West & East & \\
\hline $\mathrm{T}$ & 564 & 544 & \\
\hline$\sigma_{\mathrm{T}} / \sqrt{\sigma_{\mathrm{T}}}(1$ tailed $)$ & .000 & .000 & \\
$\mathrm{p}$. value & 3.701524 & 3.382921 & \\
\hline
\end{tabular}

Table 7: Test for distributional symmetry.

\section{A.2 Opening claims - all treatments}

\section{A.2.1 Frequencies}

\begin{tabular}{|l|l|l|l|}
\hline & Frequency & Percent & $\begin{array}{l}\text { Cumulative } \\
\text { Percent }\end{array}$ \\
\hline 120 & 1 & 5.0 & 5.0 \\
\hline 150 & 8 & 40.0 & 45.0 \\
\hline 170 & 2 & 10.0 & 55.0 \\
\hline 180 & 2 & 10.0 & 65.0 \\
\hline 200 & 6 & 30.0 & 95.0 \\
\hline 220 & 1 & 5.0 & 100.0 \\
\hline Total & 20 & 100.0 & \\
\hline
\end{tabular}

Table 8: BDM - Frequency distribution of Bargainer East's claims

\begin{tabular}{|c|l|l|l|}
\hline & Frequency & Percent & $\begin{array}{l}\text { Cumulative } \\
\text { Percent }\end{array}$ \\
\hline 140 & 2 & 10.0 & 10.0 \\
\hline 150 & 8 & 40.0 & 50.0 \\
\hline 160 & 3 & 15.0 & 65.0 \\
\hline 170 & 1 & 5.0 & 70.0 \\
\hline 180 & 3 & 15.0 & 85.0 \\
\hline 190 & 1 & 5.0 & 90.0 \\
\hline 200 & 2 & 10.0 & 100.0 \\
\hline Total & 20 & 100.0 & \\
\hline
\end{tabular}


Table 9: FXD - Frequency distribution of Bargainer East's claims

\begin{tabular}{|l|l|l|l|}
\hline & Frequency & Percent & $\begin{array}{l}\text { Cumulative } \\
\text { Percent }\end{array}$ \\
\hline 140 & 1 & 5.0 & 5.0 \\
\hline 150 & 6 & 30.0 & 35.0 \\
\hline 155 & 2 & 10.0 & 45.0 \\
\hline 160 & 3 & 15.0 & 60.0 \\
\hline 170 & 2 & 10.0 & 70.0 \\
\hline 180 & 3 & 15.0 & 85.0 \\
\hline 200 & 1 & 5.0 & 90.0 \\
\hline 210 & 1 & 5.0 & 95.0 \\
\hline 280 & 1 & 5.0 & 100.0 \\
\hline Total & 20 & 100.0 & \\
\hline
\end{tabular}

Table 10: FXD - Frequency distribution of Bargainer East's claims

\section{A.2.2 Acceptances}

Ranks

\begin{tabular}{|c|l|r|r|r|}
\hline & $\begin{array}{l}\text { West's } \\
\text { response }\end{array}$ & $\mathrm{N}$ & Mean Rank & $\begin{array}{c}\text { Sum of } \\
\text { Ranks }\end{array}$ \\
\hline \multirow{3}{*}{ East's claim } & $\mathrm{A}$ & 10 & 14.75 & 147.50 \\
\cline { 2 - 5 } & $\mathrm{R}$ & 10 & 6.25 & 62.50 \\
\cline { 2 - 5 } & Total & 20 & & \\
\hline
\end{tabular}

Test Statistics ${ }^{(\mathrm{b})}$

\begin{tabular}{|c|c|}
\hline & East's claim for himself \\
\hline Mann-Whitney U & 7.500 \\
\hline Wilcoxon W & 62.500 \\
\hline $\mathrm{Z}$ & -3.370 \\
\hline Asymp. Sig. (2-tailed) & .001 \\
\hline Exact Sig. [2*(1-tailed Sig.)] & $.000^{(\mathrm{a})}$ \\
\hline \multicolumn{2}{|l|}{ a Not corrected for ties. } \\
\hline \multicolumn{2}{|c|}{ ' Grouping Variable: BDM: West's response } \\
\hline
\end{tabular}

Table 11: BDM - Test for equality of medians between accepted and rejected offers in the first round. 


\begin{tabular}{|l|l|l|l|l|}
\hline & West's response & $\mathrm{N}$ & Mean Rank & Sum of Ranks \\
\hline \multirow{3}{*}{ East's claim } & $\mathrm{A}$ & 13 & 8.58 & 111.50 \\
\cline { 2 - 5 } & $\mathrm{R}$ & 7 & 14.07 & 98.50 \\
\cline { 2 - 5 } & Total & 20 & & \\
\hline
\end{tabular}

Test Statistics ${ }^{(\mathrm{b})}$

\begin{tabular}{|l|l|}
\hline & East's claim \\
\hline Mann-Whitney U & 20.500 \\
\hline Wilcoxon W & 111.500 \\
\hline Z & -2.055 \\
\hline Asymp. Sig. (2-tailed) & .040 \\
\hline Exact Sig. $\quad[2 *(1$-tailed & $.046^{(\text {a })}$ \\
\hline \\
\hline${ }^{\text {a }}$ Not corrected for ties. \\
\hline${ }^{\text {b }}$ Grouping Variable: FIXED: West's response \\
\hline
\end{tabular}

Table 12: FXD - Test for equality of medians between accepted and rejected offers in the first round.

\begin{tabular}{|l|l|l|l|l|}
\hline & West's response & $\mathrm{N}$ & Mean Rank & Sum of Ranks \\
\hline \multirow{3}{*}{ East's claim } & $\mathrm{A}$ & 13 & 10.12 & 131.50 \\
\cline { 2 - 5 } & $\mathrm{R}$ & 7 & 11.21 & 78.50 \\
\cline { 2 - 5 } & Total & 20 & & \\
\hline
\end{tabular}

\section{Test Statistics ${ }^{(\mathbf{b})}$}

\begin{tabular}{|c|c|}
\hline & East's claim \\
\hline Mann-Whitney U & 40.500 \\
\hline Wilcoxon W & 131.500 \\
\hline $\mathrm{Z}$ & -.403 \\
\hline Asymp. Sig. (2-tailed) & .687 \\
\hline $\begin{array}{lll}\text { Exact } & \text { Sig. } & {\left[2^{*}(1 \text {-tailed }\right.} \\
\text { Sig. })] & \end{array}$ & $.699^{(\mathrm{a})}$ \\
\hline \multicolumn{2}{|l|}{ a Not corrected for ties. } \\
\hline \multicolumn{2}{|c|}{$\begin{array}{l}\text { b Grouping Variable: DISCOUNT: West's response }(0=\text { accept, } \\
1=\text { reject) }\end{array}$} \\
\hline
\end{tabular}

Table 13: DSC - Test for equality of medians between accepted and rejected offers in the first round. 


\section{A.3 Comparison of Bargainer East's claim in all treatments}

\section{A.3.1 Location}

In the first instance a Wilcoxon-Mann-Whitney test was performed on the claims by bargainers of type East (first movers) to check for a difference in medians. The results are reported in the following table.

\begin{tabular}{|c|c|c|c|c|}
\hline & & $\mathrm{N}$ & Mean Rank & Sum of Ranks \\
\hline \multirow{4}{*}{ FIXED - BDM } & $\begin{array}{l}\text { Negative } \\
\text { ranks }\end{array}$ & $8^{(a)}$ & 9.38 & 75.00 \\
\hline & $\begin{array}{l}\text { Positive } \\
\text { Ranks }\end{array}$ & $6^{(\mathrm{b})}$ & 5.00 & 30.00 \\
\hline & Ties & $6(5)^{(c)}$ & & \\
\hline & Total & $20(19)$ & & \\
\hline \multirow{4}{*}{ DISCOUNT - BDM } & $\begin{array}{l}\text { Negative } \\
\text { Ranks }\end{array}$ & $9^{(\mathrm{d})}$ & 9.50 & 85.50 \\
\hline & $\begin{array}{l}\text { Positive } \\
\text { Ranks }\end{array}$ & $8(7)^{(e)}$ & $8.44(7.21)$ & $67.50(50.50)$ \\
\hline & Ties & $3(3)^{(f)}$ & & \\
\hline & Total & $20(19)$ & & \\
\hline \multirow{4}{*}{ DISCOUNT - FIXED } & $\begin{array}{l}\text { Negative } \\
\text { Ranks } \\
\end{array}$ & $6^{(\mathrm{g})}$ & 7.67 & 46.00 \\
\hline & $\begin{array}{l}\text { Positive } \\
\text { Ranks }\end{array}$ & $8(7)^{(h)}$ & $7.38(6.43)$ & $59.00(45.00)$ \\
\hline & Ties & $6(6)^{(\mathrm{i})}$ & & \\
\hline & Total & $20(19)$ & & \\
\hline \multicolumn{5}{|c|}{$\begin{array}{l}\text { Note: all variables refer to East's claim for himself in the various treatments. Data in } \\
\text { parenthesis refer to the case where outliers are included, which however does not affect the } \\
\text { calculations for the statistic }\end{array}$} \\
\hline \multicolumn{5}{|c|}{${ }^{\mathrm{a}}$ FIXED $<$ BDM; ${ }^{\mathrm{b}}$ FIXED $>$ BDM; ${ }^{\mathrm{c}}$ BDM $=$ FIXED } \\
\hline \multicolumn{5}{|c|}{ 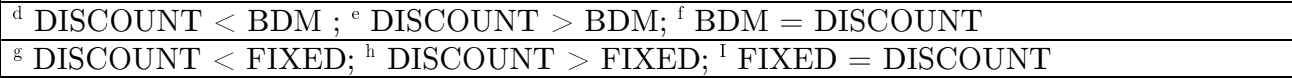 } \\
\hline
\end{tabular}

Test Statistics ${ }^{(c)}$

\begin{tabular}{|l|l|l|l|}
\hline & FIXED - BDM & DISCOUNT - BDM & DISCOUNT - FIXED \\
\hline $\mathrm{Z}$ & $-1.420^{(\mathrm{a})}$ & $-.428(-.909)^{(\mathrm{a})}$ & $-.411(-.035)^{(\mathrm{b})}$ \\
\hline $\begin{array}{l}\text { Asy. Sig. } \\
(2 \text {-tailed })\end{array}$ & .156 & $.669(.363)$ & $.681(.972)$ \\
\hline${ }^{\mathrm{a}}$ Based on positive ranks. & \\
\hline \multicolumn{2}{|l}{${ }^{\mathrm{b}}$ Based on negative ranks. } \\
\hline
\end{tabular}

Table 14: Wilcoxon test for equality of medians in the distribution of East's claim in all treatments.

The Wilcoxon test however relies on the assumption that the observations come from the same distribution, in particular assuming identity of variance. As - based on test which follow in this appendices - equality of variance (and surely of distribution) is rejected, a 
Robust Rank Order test (which is appropriate in this case) was performed. The statistic ${ }^{38}$ is calculated as

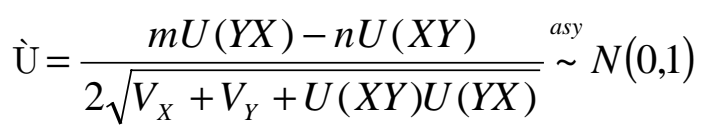

where $\mathrm{U}(\mathrm{YX})$ is the average of $\mathrm{U}\left(\mathrm{YX}_{\mathrm{i}}\right)$, the number of observations in $\mathrm{Y}$ placed ranked below each of the $\mathrm{m}$ observations $\mathrm{X}_{\mathrm{i}}$ in $\mathrm{X} ; \mathrm{V}_{\mathrm{X}}$ is the sum of the squared deviations of $\mathrm{U}\left(\mathrm{YX}_{\mathrm{i}}\right)$ around the mean (and similarly for the symmetric variables).

\begin{tabular}{|l|l|l|l|l|}
\hline $\mathrm{U}(\mathrm{FXD}, \mathrm{BDM})=12$ & $\mathrm{U}(\mathrm{BDM}, \mathrm{FXD})=8$ & $\mathrm{~V}_{\mathrm{FXD}}=378$ & $\mathrm{~V}_{\mathrm{BDM}}=819$ & $\mathrm{U}=1.1124$ \\
\hline $\mathrm{U}(\mathrm{DSC}, \mathrm{BDM})=10.65$ & $\mathrm{U}(\mathrm{BDM}, \mathrm{DSC})=9.35$ & $\mathrm{~V}_{\mathrm{DCS}}=456.55$ & $\mathrm{~V}_{\mathrm{BDM}}=876.55$ & $\mathrm{U}=0.3434$ \\
\hline $\mathrm{U}(\mathrm{DSC}, \mathrm{FXD})=8.8$ & $\mathrm{U}(\mathrm{FXD}, \mathrm{DSC})=10.9$ & $\mathrm{~V}_{\mathrm{DSC}}=617$ & $\mathrm{~V}_{\mathrm{FXD}}=701.7$ & $\mathrm{U}=-0.5581$ \\
\hline
\end{tabular}

Table 15: Robust Rank Order test for equality of medians in the distribution of East's claim in all treatments.

Finally, in support of the above note that the median unbiased estimate of the treatment effect can be computed as $\hat{\Delta}=\operatorname{med}\left(\mathrm{X}_{\mathrm{i}^{-}} \mathrm{Y}_{\mathrm{j}}\right)=0$.

\section{A.3.2 Dispersion}

The results reported below are for the Ansari-Bradley test. Similar results are obtained with other test (e.g Siegel-Tuckey) which assume equality of median in the underlying populations.

\begin{tabular}{|c|c|c|}
\hline & $\mathrm{BDM}$ & FXD \\
\hline $\begin{array}{l}\text { FXD } \\
\text { p. value (1 tailed })\end{array}$ & $\begin{array}{l}1.491849 \\
.07\end{array}$ & $\cdot$ \\
\hline $\begin{array}{l}\text { DSC } \\
\text { p. value (1 tailed) }\end{array}$ & $\begin{array}{l}1.69973 \\
.05\end{array}$ & $\begin{array}{l}0.6353 \\
.26 \\
\end{array}$ \\
\hline \multicolumn{3}{|c|}{$\begin{array}{l}\text { Each cell reports the value of the Ansari-Bradley statistic for the } \\
\text { test of } H_{0}: \sigma_{\text {row }} / \sigma_{\text {column }}=1 \text { against the one sided alternative of } H_{\Lambda} \text { : } \\
\sigma_{\text {row }} / \sigma_{\text {column }}>1 \text {. The statistic is distributed as a standard normal } \\
\text { distribution under the null. }\end{array}$} \\
\hline
\end{tabular}

Table 16: Robust Rank Order test for equality of medians in the distribution of East's claim in all treatments.

\section{A.3.3 Symmetry}

The tests are based on Palomino et al. (1981) (see appendix A.1.1).

${ }^{38}$ Tabled values for this statistic can be found in Fligner et al (1981). The distribution of the statistic under the null of no change in location approaches the standard normal distribution as the sample sizes increase (as in the case for this paper). See for instance Siegel and Castellan (1988). 


\begin{tabular}{|l|l|l|l|}
\hline & BDM & FXD & DSC \\
\hline $\mathrm{T}$ & 68 & 322 & 511 \\
\hline$\sigma_{\mathrm{T}}{\sqrt{\sigma_{\mathrm{T}}}}_{\mathrm{p}}$ p. value 1 tailed $)$ & .39775 .23 & 19088.55 & 28111.14 \\
\hline
\end{tabular}

Table 17: Test for distributional symmetry - East's claim in all treatments.

\section{A.3.4 Correlations}

\begin{tabular}{|c|c|c|c|c|c|c|}
\hline & & $\begin{array}{l}\text { Limit price } \\
\text { for bargainer } \\
\text { west }\end{array}$ & $\begin{array}{l}\text { Limit price } \\
\text { for bargainer } \\
\text { East }\end{array}$ & \begin{tabular}{|l|} 
Limit price \\
differential (i.e. \\
East-West)
\end{tabular} & $\begin{array}{l}\text { Discount rates } \\
\text { corrsponding } \\
\text { to West's cost }\end{array}$ & $\begin{array}{|lr|}\text { Discount rates } \\
\text { corrsponding } & \text { to } \\
\text { East's cost } & \\
\end{array}$ \\
\hline \multirow{3}{*}{$\mathrm{BDM}$} & $\begin{array}{l}\text { Correlation } \\
\text { Coefficient }\end{array}$ & .157 & -.074 & -.210 & -.164 & .041 \\
\hline & Sig. (1-tailed) & .194 & .347 & .121 & .184 & .415 \\
\hline & $\mathrm{N}$ & 20 & 20 & 20 & 20 & 20 \\
\hline \multirow{3}{*}{ FXD } & $\begin{array}{l}\text { Correlation } \\
\text { Coefficient }\end{array}$ & $.446(* *)$ & -.059 & $-.402(*)$ & $-.441(* *)$ & .066 \\
\hline & Sig. (1-tailed) & .006 & .375 & .011 & .007 & .361 \\
\hline & $\mathrm{N}$ & 20 & 20 & 20 & 20 & 20 \\
\hline \multirow{3}{*}{ DSC } & $\begin{array}{l}\text { Correlation } \\
\text { Coefficient }\end{array}$ & $.463(* *)$ & -.163 & $-.658(* *)$ & $-.459(* *)$ & .160 \\
\hline & Sig. (1-tailed) & .004 & .184 & .000 & .004 & .192 \\
\hline & $\mathrm{N}$ & 20 & 20 & 20 & 20 & 20 \\
\hline
\end{tabular}

Table 18: Correlations based on Kendall's $\tau$ test - East's offer in all treatments (all observations)

\begin{tabular}{|c|c|c|c|c|c|c|}
\hline & & $\begin{array}{l}\text { Limit price } \\
\text { for bargai- } \\
\text { ner West }\end{array}$ & \begin{tabular}{|l|} 
Limit price \\
for \\
bargainer \\
East
\end{tabular} & $\begin{array}{lr}\text { Limit } & \text { price } \\
\text { differential } & \text { (i.e. } \\
\text { East-West) } & \\
\end{array}$ & $\begin{array}{l}\text { Discount rates corre- } \\
\text { sponding to West's } \\
\text { cost }\end{array}$ & $\begin{array}{lr}\text { Discount rates } \\
\text { corresponding to } \\
\text { East's cost }\end{array}$ \\
\hline \multirow{3}{*}{ BDM } & $\begin{array}{l}\text { Correlation } \\
\text { Coefficient }\end{array}$ & .244 & -.125 & -.301 & -.252 & .090 \\
\hline & Sig. (1-tailed) & .097 & .259 & .052 & .090 & .323 \\
\hline & $\mathrm{N}$ & 19 & 19 & 19 & 19 & 19 \\
\hline \multirow{3}{*}{ FXD } & $\begin{array}{l}\text { Correlation } \\
\text { Coefficient }\end{array}$ & $.546(* *)$ &.- .092 & $-.496(* *)$ & $-.541(* *)$ & .101 \\
\hline & Sig. (1-tailed) & .001 & .313 & .003 & .002 & .298 \\
\hline & $\mathrm{N}$ & 19 & 19 & 19 & 19 & 19 \\
\hline \multirow{3}{*}{ DSC } & $\begin{array}{l}\text { Correlation } \\
\text { Coefficient }\end{array}$ & $.409(*)$ & -.097 & $-.628(* *)$ & $-.404\left(^{*}\right)$ & .092 \\
\hline & Sig. (1-tailed) & .012 & .301 & .000 & .013 & .313 \\
\hline & $\mathrm{N}$ & 19 & 19 & 19 & 19 & 19 \\
\hline
\end{tabular}

Table 19: Correlations based on Kendall's $\tau$ test - East's offer in all treatments (no outliers) 


\begin{tabular}{|l|l|l|l|l|}
\hline \multicolumn{2}{|l|}{} & $\begin{array}{l}\text { Limit price for } \\
\text { bargainer west }\end{array}$ & $\begin{array}{l}\text { Limit price for } \\
\text { bargainer East }\end{array}$ & $\begin{array}{l}\text { Limit price differential } \\
\text { (i.e. East-West) }\end{array}$ \\
\hline $\begin{array}{l}\text { West's } \\
\text { offer in the } \\
\text { second } \\
\text { round }\end{array}$ & $\begin{array}{l}\text { Correlation } \\
\text { Coefficient }\end{array}$ & .191 & -.113 & -.187 \\
\cline { 2 - 5 } & sig. (1-tailed) & .245 & .343 & .246 \\
\cline { 2 - 5 } & $\mathrm{N}$ & 10 & 10 & 10 \\
\hline \multirow{2}{*}{ ** Correlation is significant at the .01 level (1-tailed). }
\end{tabular}

Table 20: BDM - Correlations based on Kendall's $\tau$ test - counteroffers 
B Structure of the game in the three treatments (picture handed out to subjects)

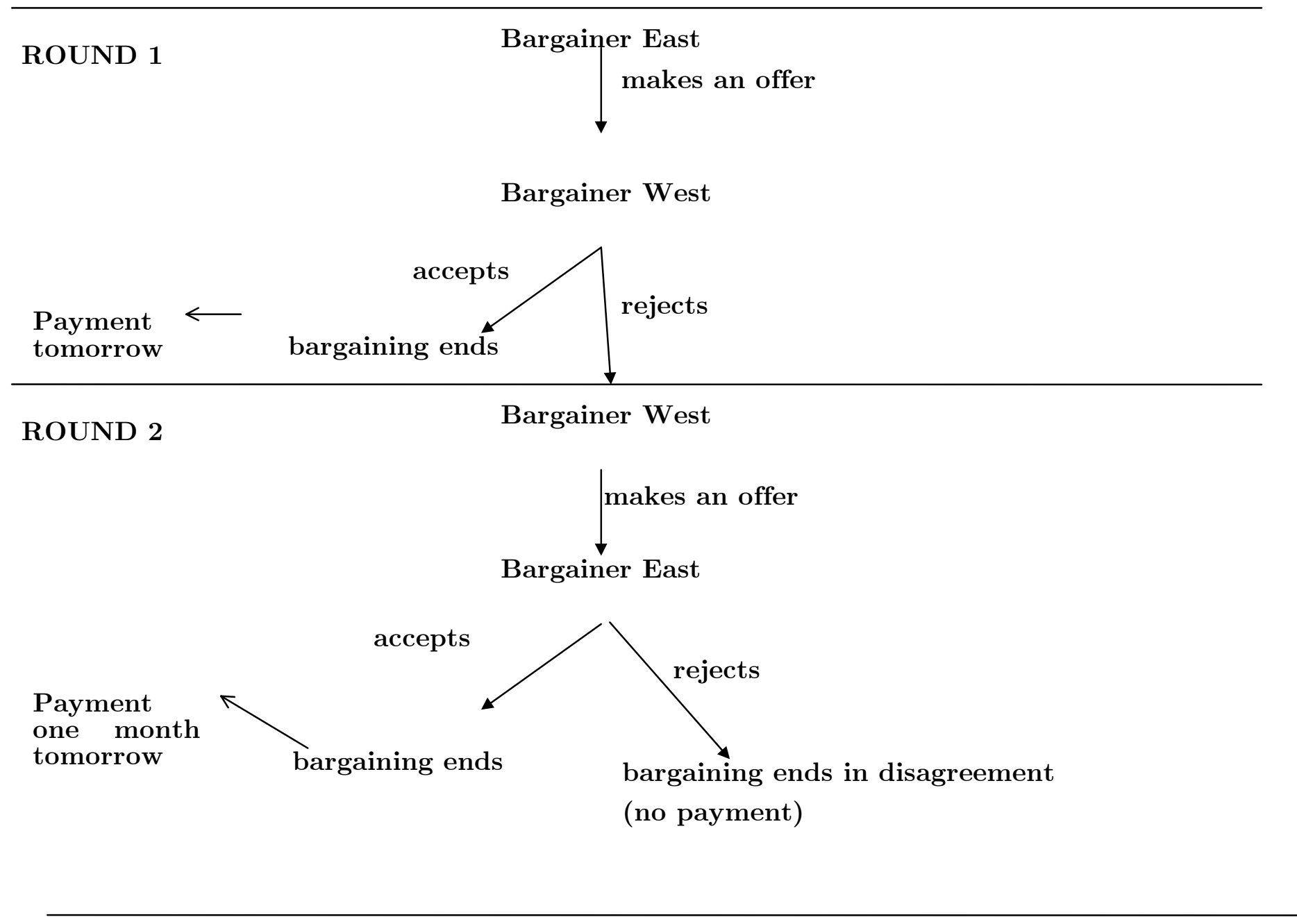

Figure 18: Structure of negotiations: BDM 


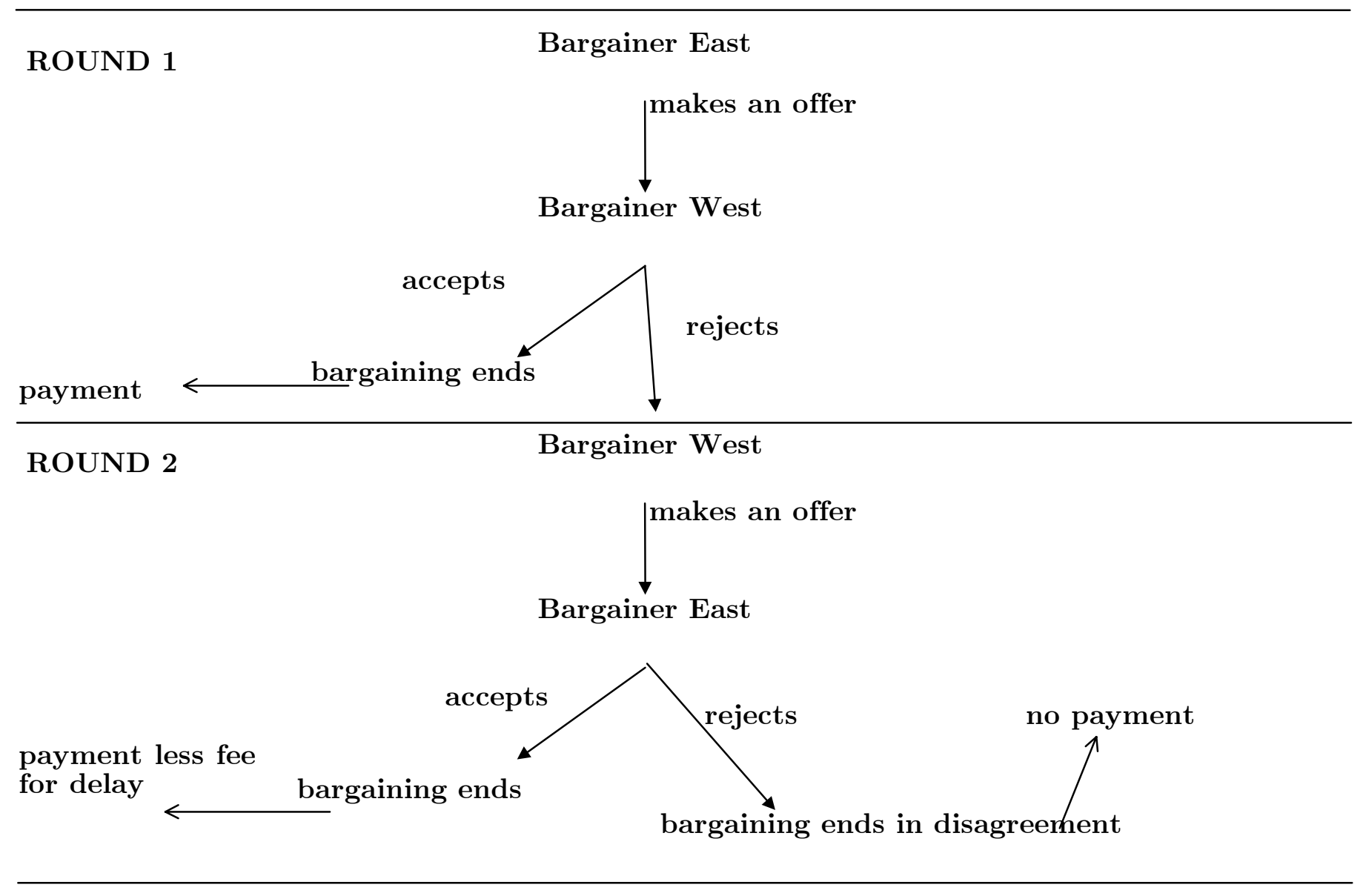

Figure 19: Structure of the bargain: FXD 
ROUND 1

\section{Bargainer East}
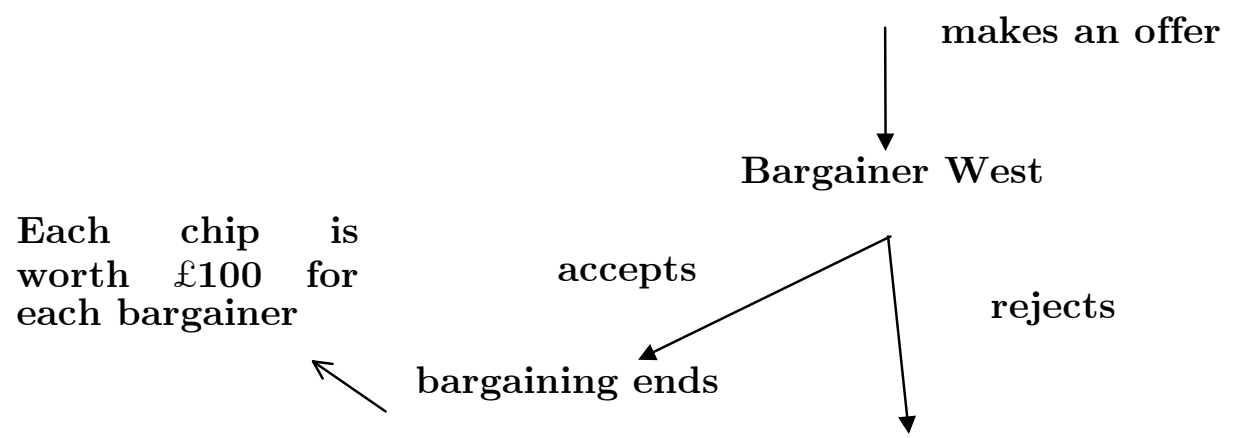

ROUND 2

Bargainer West

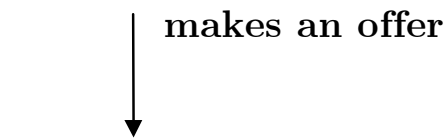

Bargainer East

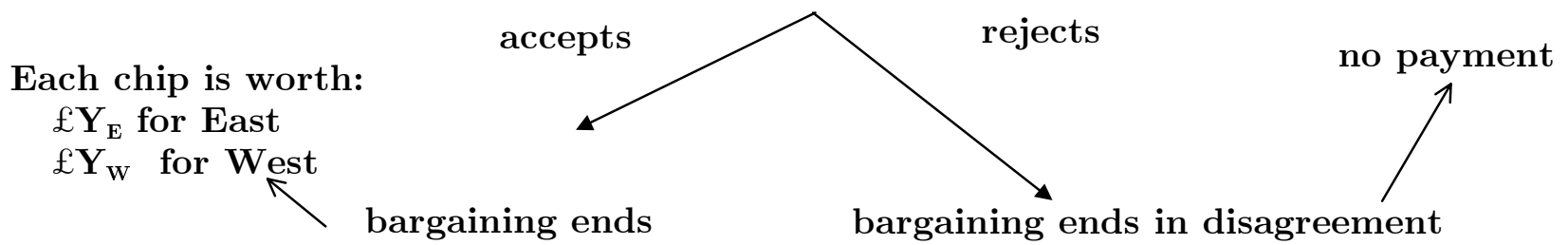

Figure 20: Structure of the bargain: DSC 


\section{Instructions ${ }^{1}$ \\ BDM TREATMENT}

\section{Time Preferences Elicitation Procedure}

Note well: you are not allowed to talk to the other participants at any time for the duration of the experiment. If you have a question, please raise your hand. Please note that you all have the same instructions.

You are about to take part in an experiment to study the bargaining behaviour of people over time. This project has been funded by QMW's Social Science Research Fund. This first part of the experiment gives an indication of how you view time. In the second part of the experiment, you will be asked to bargain with another participant over the division of $£ 30000$. You will receive instructions about the second part of the experiment later on. Please note that there is no "correct" way to act in this experiment, and you are not expected to behave in any particular way.

By agreeing to participate you have earned $£ 300^{\circ} 000$ which can be collected at a later date. There are two types of delay, and we will carry out two versions of the experiment, the "one month version" and the "two months version". In the "one month version" the money is available for collection one month tomorrow; in the "two months version" the money is available for collection two months tomorrow. At the end of the session, which of the two versions "counts" will be selected at random, determining your final payment.

For each of the two versions you will be given the opportunity to anticipate collection of your money to tomorrow; however, for this you will have to pay a price. Think about how much it is worth for you to collect the money earlier, both, in the one-month case and the two-month case. Whether you will collect money now or later is decided by the following procedure:

- You will shortly be asked to write down a number between 0 and 299, to which we'll refer as limit price on each of the two LIMIT PRICE FORMS available to you (one for the "one month" version and one for the "two months version". Obviously you can write different numbers on each of the two forms. When you are done hand the forms to the assistant.

- An assistant will draw two random numbers (of three digits each), one for the "one month version" and one for the "two months version".

- Each number has the same probability of being drawn.

- For those whose limit price is higher than the number drawn, payment will take place tomorrow, but net of as price (in hundreds of liras) equal to the number drawn by the experimenter.

- For those whose limit price is lower or equal to the number drawn, payment of the full amount (£30.000) will take place either with one month delay (i.e. one month tomorrow for the "one month version") or with two months delay (i.e. two months tomorrow for the "two months version").

\footnotetext{
${ }^{1}$ What follows is a translation of the original instructions, which were in Italian.
} 
Thus the limit price you state determines directly NOT HOW MUCH money you will receive, but WHETHER you will receive a smaller amount earlier (tomorrow), or the full amount (£30.000) later.

At the two extremes, if you put a limit price of 299 on your form, you can be almost sure that you will manage to anticipate the collection of your money, but the price you'll have to pay may be up to $299 \times 100=£ 29^{\circ} 900$. On the other hand, if you state 0 you will be sure that you will not have to pay anything, but collection will be delayed of an extra one or two months (depending on the version) for sure.

Note as well that no payment can be made immediately, and in all cases you will have to come back to collect your money.

At the end the experimenter will select on of the two versions at random, and your payment will proceed accordingly. 
Here are two hypothetical examples to make sure this procedure is clear to you. The examples below are based on a hypothetical prize of $£ 12^{\circ} 000$.

Example 1

\begin{tabular}{|c||}
\hline \hline LIMIT PRICE FORM \\
ONE MONTH
\end{tabular}

\begin{tabular}{||c||}
\hline \hline \multicolumn{1}{||c||}{ YOUR PERSONAL RECORD (FOR YOU TO KEEP) } \\
ONE MONTH
\end{tabular}

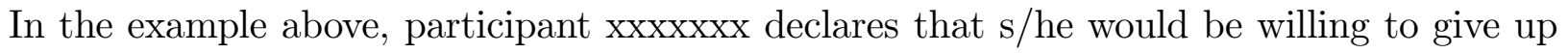
$£ 11.900$ in order to avoid having to come back one month tomorrow. The numbers drawn are 1 , 1 and 6 , which yield $£ 116 \times 100$, that is $£ 11^{\circ} 600$. Since this amount is smaller than the $£ 11^{\circ} 900$ declared by participant xxxxxxx, then if the "one month version" of the experiment is selected s/he will give up $£ 11^{\circ} 600$, and collect the amount of $£\left(12^{\circ} 000-11^{\circ} 600\right)=£ 400$ the next day. Example 2

\section{LIMIT PRICE FORM \\ TWO MONTH}

I wish to give up $£ 100$ to anticipate collection to tomorrow rather than pay nothing and receive the whole amount with two month delay | Personal Identification Code: yyyyyyy

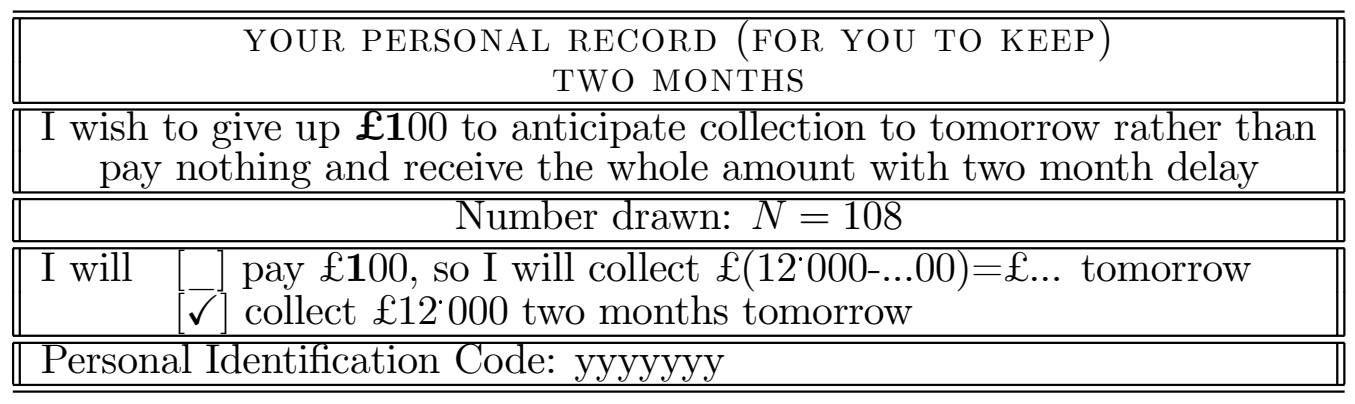

In this example participant yyyyyyy has declared that s/he wishes to pay $£ 100$ rather than wait two months longer to collect the money. The numbers drawn are 1,0 and 8 , which correspond to $£ 108 \times 100$, that is $£ 10^{*} 800$. Since this amount is greater than the $£ 100$ declared by participant yyyyyyy, then if the "two months version" of the experiment is selected s/he will collect the full amount (cioé £12000) two months tomorrow. 


\begin{tabular}{||c||}
\hline \hline \multicolumn{2}{|c||}{ LIMIT PRICE FORM } \\
ONE MONTH
\end{tabular}

\begin{tabular}{|c|c|}
\hline \multicolumn{2}{|c|}{$\begin{array}{l}\text { LIMIT PRICE FORM } \\
\text { TWO MONTHS }\end{array}$} \\
\hline \multicolumn{2}{|c|}{$\begin{array}{c}\text { wish to give up } £-00 \text { to anticipate collection to tomorrow rather than } \\
\text { pay nothing and receive the whole amount with two month delay }\end{array}$} \\
\hline Personal Identification Code & adhesive label here \\
\hline
\end{tabular}

\begin{tabular}{||c||}
\hline \hline \multicolumn{1}{||c||}{ YOUR PERSONAL RECORD (FOR YOU TO KEEP) } \\
ONE MONTH
\end{tabular}




\section{BARGAINING - BDM ${ }^{2}$}

Instruction SheEt 1 (PRE-NEgotiations instructions)- BARGAiner EAst

Note well: you are not allowed to talk to the other participants at any time for the duration of the experiment. If you have a question, please raise your hand. Please note that you all have the same instructions.

Before we continue, please check the content of the information pack which you have been given; it contains:

instruction sheets, as follows:

\section{Instruction Sheet 1 - pre-negotiation instructions (this one);}

Instruction Sheet 2 - Bargaining Procedure;

$\square$ "Personal Identification Code" labels;

example;

figure;

bargaining form;

notepad and pen.

Please, verify the pack's contents, using the checklist above (please, check the appropriate box to make sure your pack contains everything).

In the bargains in which you are about to engage you will be matched randomly and anonymously with another participant from the other room. To retain anonimity with the other participants and the experimenter, during negotiationsyou will be identified by your "Personal Identification Code". Later on you will need to affix one label onto the BARGAINING FORM that will be provided in the space above the heading "Personal Identification Code for Bargainer East (West)". The same procedure is used in the other room. You will be randomly matched by the experimenter with a participant from the other room, identified by the label shown above the heading "Personal Identification Code for Bargainer West (East)" on the BARGAINING FORM that you will receive.

\footnotetext{
${ }^{2}$ Italics refers to the instructions available in the version for Bargainer West.
} 
Instruction SHEET 2 (BARGAining PROCEDURE)

Note well: you are not allowed to talk to the other participants at any time for the duration of the experiment. If you have a question, please raise your hand. Please note that you all have the same instructions.

We will shortly proceed to the actual bargaining phase. The procedure is simple, and works as follows. You and a negotiator randomly selected from the other room have to agree over how to share $£ 30000$ between the two of you. You have at most two rounds to reach an agreement; if you fail to reach an agreement, then none of you will receive any of the $£ 30000$. On the other hand:

- an agreement reached with the other bargainer in the first round entails payment tomorrow (at a time which is convenient for you);

- an agreement reached with the other bargainer in the second round entails payment a month tomorrow (at a time which is convenient to you);

- failure to reach an agreement by the end of the second round implies that none of you will receive any of the $£ 30000$.

If the bargaining form is incorrectly filled in, the agreement is void, and neither of you will receive any of the $£ 30000$.

Participants in this room are referred to as "Bargainer East (West)", whereas participants in the other room are referred to as "Bargainer West (East)". Bargainers East (participants in this room) start first. This experiment will be carried out one time only.

In order to exchange offers, you will have to use the BARGAINING FORM provided. The bottom part of the form reports how much both you and the other bargainer declared you would be willing to pay out of $£ 30000$ in order to avoid having to wait one month. The proposal takes the form of an amount of money offered to the other bargainer, whereby the proposer keeps the residual for him/herself.

The structure of the bargain is depicted in the figure in your folder, and the details are as follows:

Round 1: Fill in the corresponding blank in the BARGAINING FORM with your offer to Bargainer West. When you are done, raise your hand, and an experimenter will collect your form and take it to Bargainer West. If Bargainer West accepts your proposal, then an experimenter will record the amounts you have agreed on the BARGAINING FORM and collect it. If Bargainer West rejects your proposal, the negotiation enters round 2.

Round 2 :You will receive the BARGAIning FORM, filled in with an offer for you. You can either accept or reject this offer.

1. If you decide to accept the proposal, circle ACCEPT on the form and fill in the sum you are accepting. An experimenter will record the amounts you have agreed on the BARGAINING FORM and will collect it.

2. If you decide to reject the proposal, circle REJECT on the form and fill in the sum you are rejecting. An experimenter will record on the form that no agreement was reached, in which case each of you earns 0 ; the experimenter will then collect the form. 
A final remark before we start: this experiment is not an "intelligence" test, and you are not expected to behave in any particular way.

Variation for Bargainers West

Round 1 :You will receive the BARGAINING FORM, filled in with an offer for you. You can either accept or reject this offer.

(a) If you decide to accept the proposal, circle ACCEPT on the form and fill in the sum you are accepting. An experimenter will record the amounts you have agreed on the BARGAINING FORM and will collect it.

(b) If you decide to reject the proposal, circle REJECT on the form and fill in the sum you are rejecting. At this point an experimenter will announce that the negotiation enters round 2.

Round 2 :Fill in ill the corresponding blank in the BARGAINING FORM with your offer to Bargainer East. When you are done, raise your hand, and an experimenter will collect your form and take it to Bargainer East. If Bargainer East accepts your proposal, then an experimenter will record the amounts you have agreed on the BARGAINING FORM and collect it. If Bargainer East rejects your proposal, an experimenter will record on the form that no agreement was reached, in which case each of you earns 0; the experimenter will then collect the form. 


\section{Example}

The following example is just to give you an idea of how the experiment works.

Suppose that two randomly matched negotiators bargain over the division of $£ 150000$, and in the end an experimenter collects the following form:

\begin{tabular}{|c|c|}
\hline \multicolumn{2}{|c|}{ Bargaining form } \\
\hline Round 1 & I Bargainer East offer $£ 150000$ to you \\
\hline (payment tomorrow) & I Bargainer West accept/reject $£ 150000$ \\
\hline Round 2 & I Bargainer West offer $£ 1000$ to you \\
\hline (Payment one month tomorrow) & I Bargainer East accept/reject $£ 1000$ \\
\hline \multicolumn{2}{|c|}{$\begin{array}{l}\text { An agreement has been struck in round } 2 \text { which } \\
\text { gives } £ 1000 \text { to Bargainer East and } £ 149000 \text { to Bargainer West }\end{array}$} \\
\hline \multicolumn{2}{|c|}{ No agreement has been struck } \\
\hline $\begin{array}{ll} & 12-04-00-78 \\
\text { Personal Id. Code for Bargainer East }\end{array}$ & $\begin{array}{ll} & \text { 87-50-66-23 } \\
\text { Personal Id. Code for Bargainer West }\end{array}$ \\
\hline $\begin{array}{l}\text { Bargainer East is willing to pay: } \\
£ 24000 \text { out of } £ 150000 \text { to } \\
\text { avoid having to wait one month }\end{array}$ & $\begin{array}{l}\text { Bargainer West is willing to pay: } \\
£ 0 \text { out of } £ 150000 \text { to } \\
\text { avoid having to wait one month }\end{array}$ \\
\hline
\end{tabular}

To make sure all of you understand the procedure, please answer the following questions, and hand them to the experimenter without writing your name or identification number anywere; if any of the questionnaires contains any error, we will go through the instructions again.

1. In Round 1

(a) how much does Bargainer East offer to Bargainer West?

(b) how much of the 150000 does Bargainer East keep for him/herself?

(c) does Bargainer West accept Bargainer East's proposal?

2. In Round 2

(a) how much does Bargainer West offer to Bargainer East?

(b) how much of the 150000 does Bargainer West keep for him/herself?

(c) does Bargainer East accept Bargainer West's proposal?

3. What payment will the two bargainers receive, and when? 


\begin{tabular}{|c|c|}
\hline \multicolumn{2}{|c|}{ Bargaining form } \\
\hline $\begin{array}{c}\text { Round } 1 \\
\text { (payment tomorrow) }\end{array}$ & $\begin{array}{l}\text { I Bargainer East offer }----- \\
\text { I Bargainer West accept/reject } \\
-----\end{array}$ \\
\hline $\begin{array}{c}\text { Round } 2 \\
\text { (Payment one month tomorrow) }\end{array}$ & $\begin{array}{l}\text { I Bargainer West offer }------ \\
\text { I Bargainer East accept/reject }\end{array}$ \\
\hline \multicolumn{2}{|c|}{ 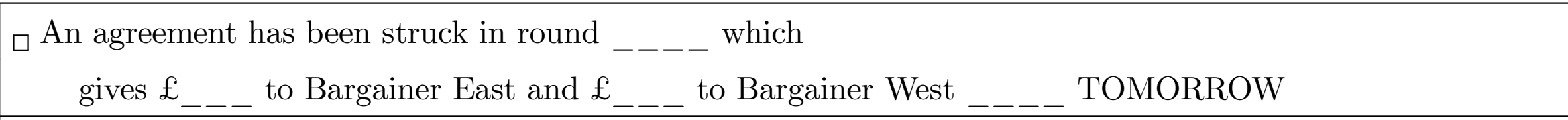 } \\
\hline \multicolumn{2}{|c|}{$\begin{array}{l}\square \text { An agreement has been struck in round }{ }_{---} \text {which } \\
\text { gives } £_{--} \text {to Bargainer East and } £_{---} \text {to Bargainer West } \ldots \ldots \text { ONE MONTH TOMORROW }\end{array}$} \\
\hline \multicolumn{2}{|l|}{$\square$ No agreement has been struck } \\
\hline Personal Identification Code for Bargainer East & Personal Identification Code for Bargainer West \\
\hline Summary of previous phase: & Summary of previous phase: \\
\hline $\begin{array}{l}\text { Bargainer East is willing to give up: } \\
\text { (out of } £ 30000) \text { to avoid having to wait one month }\end{array}$ & $\begin{array}{l}\text { Bargainer West is willing to give up: } \\
\text { (out of } £ 30000) \text { to avoid having to wait one month }\end{array}$ \\
\hline
\end{tabular}




\section{BARGAINING - FIXED}

Bargaining Procedure- Bargainer East

Note well: you are not allowed to talk to the other participants at any time for the duration of the experiment. If you have a question, please raise your hand. Please note that you all have the same instructions.

We will shortly proceed to the actual bargaining phase. The procedure is simple, and works as follows. You and a negotiator randomly selected from the other room have to agree over how to share $£ 30000$ between the two of you. You have at most three rounds to reach an agreement; if you fail to reach an agreement, then none of you will receive any of the $£ 30000$.

If an agreement is struck, you will be paid your final payoff at the end of the experiment. The amount you receive depends on when such agreement is reached; if this happens in the second round, you and the other bargainer will have to pay a delay fee, which will be randomly assigned to you. More precisely:

- if an agreement is reached with the other bargainer in the first round, your final payoff is exactly the money agreed in the bargain;

- an agreement is reached with the other bargainer in the second round, your final payoff is given by the agreed sum net of your delay fee;

- failure to reach an agreement by the end of the second round implies that none of you will receive any of the $£ 30^{\circ} 000$.

The delay fee for each bargainer is indicated at the bottom of the bargaining form. An agreement becomes void if the bargaining form is completed incorrectly. Furthermore, if agreement is reached in the second round, it becomes void if the sum agreed upon is insufficient to cover the fees for at least one bargainer. In case of void agreement neither you nor the other bargainer will earn anything.

Participants in this room are referred to as "Bargainer East (West)", whereas participants in the other room are referred to as "Bargainer West (East)". Bargainers East (participants in this room) start first. This experiment will be carried out one time only.

In order to exchange offers, you will have to use the BARGAINING FORM provided. The bottom part of the form reports delay fees for the second and third round for both you and the other bargainer. The proposal takes the form of an amount of money offered to the other bargainer, whereby the proposer keeps what remains of the $£ 30^{\circ} 000$ for him/herself.

The structure of the bargain is depicted in the figure in your folder, and the details are as follows:

(As in the BDM treatment) 


\section{Example}

The following purely hypothetical example is just to give you an idea of how the experiment works. Suppose that two randomly matched negotiators bargain over the division of $£ 150^{\circ} 000$, and that the experimenter collects the following form:

\begin{tabular}{|c|c|}
\hline \multicolumn{2}{|c|}{ Bargaining form } \\
\hline Round 1 & $\begin{array}{l}\text { I Bargainer East offer } £ 150^{\circ} 000 \text { to you } \\
\text { I Bargainer West accept/reject } £ 150^{\circ} 000\end{array}$ \\
\hline $\begin{array}{c}\text { Round } 2 \\
\text { (the delay fee must be paid) }\end{array}$ & $\begin{array}{l}\text { I Bargainer West offer } £ 1^{\circ} 000 \text { to you } \\
\text { I Bargainer East accept/reject } £ 1^{\circ} 000\end{array}$ \\
\hline \multicolumn{2}{|c|}{$\begin{array}{l}\text { An agreement has been struck in the First round which } \\
\text { gives } £=\text { to Bargainer East and } £ \quad \text { to Bargainer West }\end{array}$} \\
\hline \multicolumn{2}{|c|}{$\begin{array}{l}\text { An agreement has been struck in the Second round which } \\
\text { gives } £ 1^{\circ} 000 \text { to Bargainer East and } £ 149^{\circ} 000 \text { to Bargainer West }\end{array}$} \\
\hline \multicolumn{2}{|c|}{$\square$ No agreement has been struck } \\
\hline $\begin{array}{ll} & 12-04-00-78 \\
\text { Personal Id. code for Bargainer East }\end{array}$ & $\begin{array}{ll} & \text { 87-50-66-23 } \\
\text { Personal Id. Code for Bargainer West }\end{array}$ \\
\hline $\begin{array}{l}\text { Delay fee for Bargainer East: } \\
£ 24^{\cdot} \cdot 000 \text { (to be paid } \\
\text { if agreement is in the second round) }\end{array}$ & $\begin{array}{l}\text { Delay fee for Bargainer West: } \\
£ 0 \text { (to be paid } \\
\text { if agreement is in the second round) }\end{array}$ \\
\hline
\end{tabular}

To make sure all of you understand the procedure, please answer the following questions, and hand them to the experimenter without writing your name or identification number anywere; if any of the questionaires contains any error, we will go through the instructions again.

1. In Round 1

(a) how much does Bargainer East offer to Bargainer West?

(b) how much out of $£ 150^{\circ} 000$ does Bargainer East keep for him/herself?

(c) does Bargainer West accept Bargainer East's proposal?

2. In Round 2

(a) how much is Bargainer East's delay fee?

(b) how much is Bargainer West's delay fee?

(c) how much does Bargainer West offer to Bargainer East?

(d) how much out of $£ 150^{\circ} 000$ does Bargainer West keep for him/herself?

(e) does Bargainer East accept or reject Bargainer West's proposal?

3. Why is the agreement void?

(a) because the agreed amounts are insufficient to cover Bargainer East's delay fee (Yes/No)

(b) because the agreed amounts are insufficient to cover Bargainer West's delay fee (Yes/No)

4. What payment will the two bargainers receive? 


\begin{tabular}{|c|c|}
\hline \multicolumn{2}{|c|}{ Bargaining form } \\
\hline Round 1 & $\begin{array}{l}\text { I Bargainer East offer } £_{-----} \text {to you } \\
\text { I Bargainer West accept/reject } £_{-----}\end{array}$ \\
\hline $\begin{array}{l}\text { Round } 2 \\
\text { (the delay fee must be paid) }\end{array}$ & $\begin{array}{l}\text { I Bargainer West offer } £_{------} \text {to you } \\
\text { I Bargainer Est accept/reject } £_{-----}\end{array}$ \\
\hline \multicolumn{2}{|c|}{ 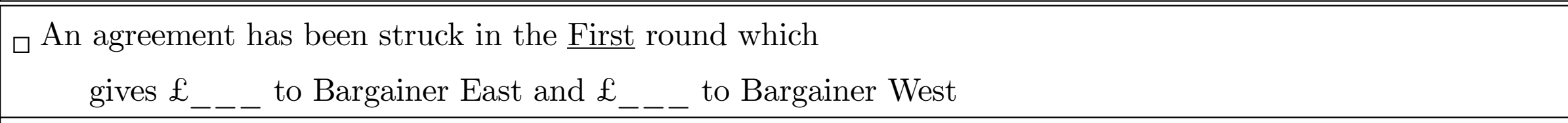 } \\
\hline \multicolumn{2}{|c|}{ 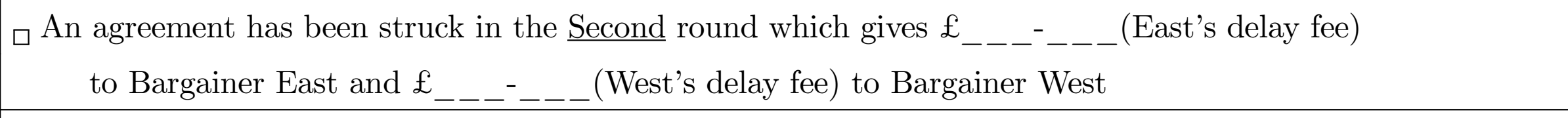 } \\
\hline \multicolumn{2}{|l|}{$\square$ No agreement has been struck } \\
\hline \multicolumn{2}{|l|}{$\square$ The agreement is void } \\
\hline Personal Identification Code for Bargainer East & Personal Identification Code for Bargainer East \\
\hline $\begin{array}{l}\text { Delay fee for Bargainer East } \\
E_{----} \text {(to be paid if agreement is in the } 2 \text { nd round) }\end{array}$ & $\begin{array}{l}\text { Delay fee for Bargainer West } \\
E_{----} \text {(to be paid if agreement is in the } 2 \text { nd round) }\end{array}$ \\
\hline
\end{tabular}




\section{BARGAINING - DISCOUNT}

BARGAINING PROCEDURE - BARGAINER EAST

Note well: you are not allowed to talk to the other participants at any time for the duration of the experiment. If you have a question, please raise your hand. Please note that you all have the same instructions.

We will shortly proceed to the actual bargaining phase. The procedure is simple, and works as follows. You and a negotiator randomly selected from the other room have to agree over how to share $£ 30000$ between the two of you. You have at most two rounds to reach an agreement; if you fail to reach an agreement, then none of you will receive any of the $£ 30000$.

Participants in this room are referred to as "Bargainer East (West)", whereas participants in the other room are referred to as "Bargainer West (East)". Bargainers East (participants in this room) start first.

If an agreement is struck, you will be paid your final payoff at the end of the experiment. The amount you receive depends on when such agreement is reached. More precisely, you will have to negotiate over the division of 300 chips. Initially each chip is worth one hundred liras (£100). The value of each chip may fall in case of disagreement. The exact value is determined based on a random procedure. It may be different for the two negotiators, and we will refer to is as $\mathbf{Y}_{\mathbf{E}}$ for Bargainer East and $\mathbf{Y}_{\mathbf{W}}$ for Bargainer West. Then:

- if an agreement is reached with the other bargainer in the first round, at the end of the experiment you will receive a payment determined as your number of chips in the agreement multiplied by $\mathbf{1 0 0}$;

- if an agreement is reached in the second round, at the end of the experiment you will receive a payment determined as your number of chips in the agreement multiplied by $\mathbf{Y}_{\mathbf{E}}$ (if you are Bargainer West) or $\mathbf{Y}_{\mathbf{W}}$ (if you are Bargainer West);

- failure to reach an agreement by the end of the second round implies that none of you will receive any of the $£ 30^{\circ} 000$.

If the bargaining form is incorrectly filled in, the agreement is void, and neither you nor the other negotiator will receive any of the $£ 30^{\circ} 000$. This experiment will be carried out one time only.

In order to exchange offers, you will have to use the BARGAINING FORM provided. The bottom part of the form reports the value of the chips in the second round for both you and the other bargainer. The proposal takes the form of an amount of chips offered to the other bargainer, whereby the proposer keeps the residual for him/herself.

The structure of the bargain is depicted in the figure in your folder, where $Y_{E}$ and $Y_{O}$ denote the value of each chip for Bargainer East and Bargainer West, respectively, in the second round. Details are as follows: (As in the BDM treatment) 


\section{Example}

The following purely hypothetical example is just to give you an idea of how the experiment works. Suppose that two randomly matched negotiators bargain over the division of 500 chips, initially worth $£ 100$ each for each player (so that the amount to be shared is $£ 50^{*} 000$ ). At the end the experimenter collects the following form:

\begin{tabular}{|c|c|}
\hline \multicolumn{2}{|c|}{ Bargaining form } \\
\hline Round 1 & $\begin{array}{l}\text { I Bargainer East offer } 500 \text { chips to you } \\
\text { I Bargainer West accept/reject } 500 \text { chips }\end{array}$ \\
\hline Round 2 & $\begin{array}{l}\text { I Bargainer West offer 1 chip to you } \\
\text { I Bargainer East accept/reject } 1 \text { chip }\end{array}$ \\
\hline \multirow{2}{*}{\multicolumn{2}{|c|}{$\begin{array}{l}{\left[\ldots \text { An agreement has been struck in the First round which gives }-c_{-} \text {chips (overall value }=£\right.} \\
\text { to Bargainer East and } \\
{[\checkmark] \text { An agreement has been struck in the Second round which gives } 1 \text { chips (overall value }=£ 50 \text { ) }} \\
\left.\text { gives } 1 \text { chip to Bargainer East and } 499 \text { chips (overall value }=£ 49^{\circ} 900\right) \text { to Bargainer West }\end{array}$}} \\
\hline & \\
\hline \multicolumn{2}{|l|}{$\square$ No agreement has been struck } \\
\hline $\begin{array}{c}12-04-00-78 \\
\text { Personal Identification Code for Bargainer East }\end{array}$ & $\begin{array}{c}\text { 87-50-66-23 } \\
\text { Personal Identification Code for Bargainer West }\end{array}$ \\
\hline $\begin{array}{c}\text { For Bargainer East each chip is worth: } \\
100 \text { liras in the first round } \\
50 \text { liras the second round }\end{array}$ & $\begin{array}{l}\text { For Bargainer West each chip is worth: } \\
100 \text { liras in the first round } \\
100 \text { liras in the second round }\end{array}$ \\
\hline
\end{tabular}

To make sure all of you understand the procedure, please answer the following questions, and hand them to the experimenter without writing your name or identification number anywere; if any of the questionaires contains any error, we will go through the instructions again.

1) In Round 1

(a) how much are the 500 chips worth to Bargainer East?

(b) how much are the 500 chips worth to Bargainer West?

(c) how many chips does Bargainer East offer to Bargainer West?

(d) how many of the 500 chips does Bargainer East keep for him/herself?

(e) does Bargainer West accept Bargainer East's proposal?

2) In Round 2

(a) how much are the 500 chips worth to Bargainer East?

(b) how much are the 500 pot worth to Bargainer West?

(c) how many chips does Bargainer West offer to Bargainer East?

(d) how many of the 500 chips does Bargainer West keep for him/herself?

(e) does Bargainer East accept Bargainer West's proposal?

1. Is a valid agreement reached? (Yes/No)

2. What payment will each of the two bargainers receive (i.e. how much are the chips they have agreed upon worth to each of them)? 


\begin{tabular}{|c|c|}
\hline \multicolumn{2}{|c|}{ Bargaining form } \\
\hline Round 1 & $\begin{array}{l}\text { I Bargainer East offer } \_---{ }_{-} \text {chips } \\
\text { I Bargainer West accept/reject }\end{array}$ \\
\hline $\begin{array}{c}\text { Round } 2 \\
\text { (the value of each chip may go down) }\end{array}$ & $\begin{array}{l}\text { I Bargainer West offer }-----{ }{ }^{\text {chips }} \\
\text { I Bargainer East accept/reject } \\
\text { I Bargainer West accept/reject }\end{array}$ \\
\hline \multicolumn{2}{|c|}{ 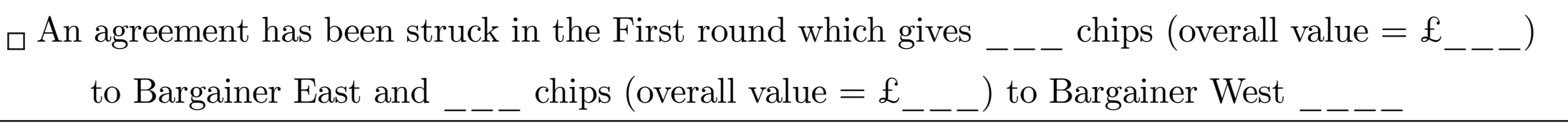 } \\
\hline \multirow{2}{*}{\multicolumn{2}{|c|}{ 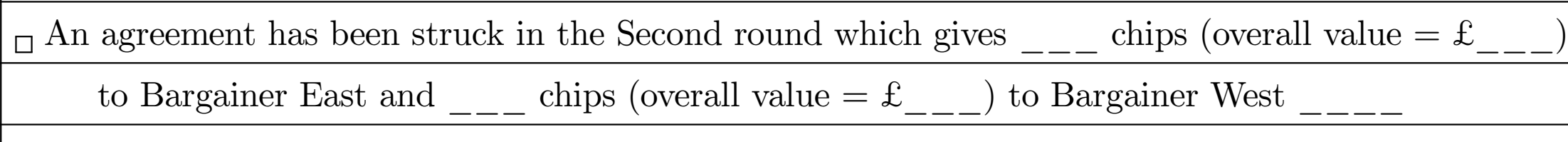 }} \\
\hline & \\
\hline \multicolumn{2}{|l|}{$\square$ No agreement has been struck } \\
\hline Personal Identification Code for Bargainer East & Personal Identification Code for Bargainer West \\
\hline For Bargainer East each chip is worth: & For Bargainer West each chip is worth: \\
\hline$£ 100 p$ in the first round & $£ 100$ in the first round \\
\hline & \\
\hline
\end{tabular}




\section{References}

Anglin, P., D. Rutheford and T. M. Springer (2001) "The Trade-off Between the Selling Price of Residential Properties and Time-on-the-Market: The Impact of Price Setting", mimeo, University of Windsor.

Ainslie, G. W. (1975) "Specious Reward: a Behavioral Theory of Impulsiveness and Impulsive Control", Psychological Bulletin, vol. 82, p.463-496.

Becker, G. M., M. H. DeGroot and J. Marschak (1964), "Measuring Utility by a SingleResponse Sequential Method", Behavioral Science, vol. 9, p. 226-232.

Benzion, U., A. Rapoport and J. Yagil (1989), Discount Rates Inferred from Decisions: an Experimental Study, Management Science, vol. 35, p. 270-284.

Bickel, W. K. and L. A. Marsch (2001) "Towards A Behavioral Economic Understanding Of Drug Dependence: Delay Discounting Processes", Addiction, vol. 96, p. 73-86.

Binmore, K., M. Osborne and A. Rubinstein (1992), "Non Cooperative Models of Bargaining", in Handbook of Game Theory with Economic Applications, R.J. Aumann and S. Hart (Eds.), North-Holland, Amsterdam.

Binmore, K., P. Morgan, A. Shaked and J. Sutton (1991), "Do People Exploit Their Bargaining Power? An Experimental Study, Games and Economic Behavior, vol.3, p. 295322.

Binmore, K., A. Shaked and J. Sutton (1985)," Testing Non-Cooperative Bargaining Theory: a Preliminary Study", American Economic Review, vol. 75, p. 1178-90.

Bohm, P., J. Linden and J. Sonnegard (1997), "Eliciting Reservation Prices: BeckerDeGroot-Marschak Mechanisms vs.Markets", Economic-Journal, vol. 107, p. 1079-89.

Bolton, G. E. and A. Ockenfels (2000) "ERC: A Theory of Equity, Reciprocity, and Competition", American Economic Review, vol. 90, p.166-193.

Burgos, A. S. Grant and A. Kajii (1997), "Bargaining and Boldness", mimeo.

Davis and Holt (1993), Experimental Economics, Princeton University Press.

Elster, J. (1998) "Emotions and Economic Theory", Journal of Economic Literature, vol. 36, p. $47-74$.

Elster, J. and G. Loewenstein (1992), Choice Over Time, Russel Sage Foundation, New York.

Fehr, E. and S. Gachter (2000), "Fairness and Retaliation: The Economics of Reciprocity", Journal of Economic Perspectives, vol. 14, p. 159-181.

Fishburn, P.C. and W. Edwards (1997), "Discount-neutral Utility Models for Denumerable Time Streams", Theory and Decisions, vol. 43, p. 139-166.

Fishburn, P.C. and A. Rubinstein (1982), "Time Preference", International Economic Review, vol. 23, p.677-694. 
Fligner, M. A., G.E. Policello II (1981) "Robust Rank Procedures For The Behrens-Fisher Problem", Journal of the American Statistical Association, vol. 76, 162-168.

Forsythe, R., J.L. Horowitz, N.E. Savin and M. Sefton (1994),"Fairness in Simple Bargaining Experiments", Games and Economic Behavior, vol. 6, p. 347-369.

Frederick, S., G. Loewenstein and T. O'Donoghue (2001) "Time discounting: a Critical Review", mimeo.

Gazzaniga, M., R. Ivry and G. Mangun (1998) Cognitive Neuroscience, W. W. Norton.

Goeree and Holt (2000) "Ten Little Treasures of Game Theory and Ten Intuitive Contradictions" Mimeo.

Guth, W. and R. Tietz (1988), "Ultimatum Bargaining for a Shrinking Cake An Experimental Analysis", in R. Tietz, W. Albers and R. Selten (Eds.), Bounded Rational Behavior in Experimental Games and Markets, Springer, Berlin.

Henrich, J., R. Boyd, S. Bowles, C. Camerer, E. Fehr, H. Gintis, and R. McElreath (2001) "In Search of Homo Economicus: Behavioral Experiments in 15 Small-Scale Societies", American Economic Review, vol. 91, p. 73-78.

Hollander, M. and D. Wolfe (1999) Nonparametric Statistical Methods, $2^{\text {nd }}$ ed., John Wiley and Sons, New York.

Kahneman, D. and A. Tversky (1979), "Prospect Theory: an Analysis of Decision Under Risk", Econometrica, vol. 47, p. 363-391.

Laibson, D. (1997), "Hyperbolic Discount Functions and Time Preference Heterogeneity", mimeo, Harvard University.

Lehmann, E. L. (1975) Nonparametrics: Statistical Methods Based on Ranks, Holden-Day Series in Probability and Statistics, McGraw - Hill, New York.

Loewenstein, G. (1987), "Anticipation and the Valuation of Delayed Consumption", Economic Journal, vol. 97, p. 666-684.

Loewenstein, G. (2001) "The Creative Destruction Of Decision Research", forthcoming in Journal of Consumer Research.

Loewenstein, G. and D. Prelec (1991), "Decision Making Over Time and Under Uncertainty: A Common Approach", Management Science, vol. 37, p. 770-786.

Loewenstein, G. and D. Prelec (1992), "Anomalies in Inrtertemporal Choice: Evidence and Interpretation, Quarterly Journal of Economics, May, p. 573-597

Loewenstein, G. and R. Thaler (1989), "Intertemporal Choice", Journal of Economic Perspectives, vol. 3, p. 181-193.

Meyer, R. F. (1976), "Preferences Over Time", in Keeney, R. L. H. Raiffa (eds.) Decisions With Multiple Objectives, Cambridge University Press.

Neelin, J., H. Sonnenschein and M. Spiegel (1988), "A Further Test of Noncooperative Bargaining Theory", American Economic Review, vol. 78, p. 824-836. 
Ochs, J. and A. Roth (1989), "An Experimental Study of Sequential Bargaining", American Economic Review, vol. 79, p. 355-384.

O’Donoghue, T. and M. Rabin (1999) "Doing it Now or Later", American Economic Review, vol. 89 , p.103-124

Ortalo-Magné, F. and Antonio Merlo (2000) "Bargaining Over Residential Real Estates: Evidence From England", mimeo, London School of Economics.

Osborne, M. and A. Rubinstein (1990) Bargaining and Markets, Academic Press, San Diego.

Prasnikar, V. and A. E. Roth (1992), "Considerations of Fairness and Strategy: Experimental Data from Sequential Games", Quarterly Journal of Economics, vol. 107, p. 865-88.

Rabin, M (1998) "Psychology and Economics", Journal of Economic Literature, vol. 36, p. $11-46$.

Randles, R.H., M. A. Fligner, G. E. Policello and D. A. Wolfe (1980) "An Asymptotically Distribution Free Test For Symmetry Versus Asymmetry", Journal of the American Statistical Association, vol. 75, 168-172.

Rapoport, A., E. Weg and D. S. Felsenthal (1990), "Effects of Fixed Costs in Two-Person Sequential Bargaining, Theory and Decision, vol. 28, p. 47-72.

Roth, A. (1995), "Bargaining Experiments", in J. Kagel and A. Roth (Eds.), Handbook of Experimental Economics, p. 253-348, Princeton University Press, Princeton, New Jersey.

Rubinstein, A. (1982) "Perfect Equilibrium in a Bargaining Model", Econometrica, vol. 50, p. 97-109.

Rubinstein, A. (2000) "Is It 'Economics and Psychology'? : The Case of Hyperbolic Discounting", mimeo, Tel-Aviv University.

Siegel, S. and N. J. Castellan (1988) Nonparametric Statistics For The Behavioral Sciences, $2^{\text {nd }}$ ed., McGraw Hill.

Starmer, C. (2000), "Developments in Non-expected Utility Theory: The Hunt for a Descriptive Theory of Choice under Risk" Journal of Economic Literature, vol. 38, p. 332382.

Thaler, R. H. (1981), "Some Empirical Evidence on Dynamic Inconsistency, Economics Letters, vol. 8, p. 201-207.

Thaler, R. H., ed. (1991) Quasi Rational Economics, Russel Sage Foundation, New York 


\section{Q Queen Mary \\ University of London}

This working paper has been produced by the Department of Economics at Queen Mary, University of London

Copyright @ 2001 Paola Manzini All rights reserved.

\section{Department of Economics}

Queen Mary, University of London

Mile End Road

London E1 4NS

Tel: +44 (0)20 78825096 or Fax: +44 (0)20 89833580

Email: j.conner@qmw.ac.uk

Website: www.econ.qmw.ac.uk/papers/wp.htm 